Published in Emerging markets review, 2016, vol. 29, pp. 200-225 which

should be cited to refer to this work.

\title{
Red obsession: the ascent of fine wine in China*
}

\author{
Philippe Masset ${ }^{1}$, Jean-Philippe Weisskopf ${ }^{1}$, Benoit Faye $^{2}$, Eric Le Fur ${ }^{2}$
}

This version: August 2016

\begin{abstract}
This article uses hammer prices from five global auction houses to analyse the price premium Bordeaux fine wine yields at Hong Kong wine auctions. We find that fine wine is on average sold at a $19 \%$ premium in Hong Kong. We further observe that the Hong Kong premium is not uniform and most pronounced for wines with perfect Parker scores and the most powerful brands. The premium has declined throughout the sample period from $60 \%$ in 2008 to a level of around 15\% since 2012. This can be attributed to the increase in knowledge on fine wine by Chinese customers.
\end{abstract}

JEL Classification: C60, F14, Q11, Q14

Keywords: Hong Kong, China, auction hammer prices, fine wine, premium, hedonic regression

* We are grateful to Douglas Cumming, Johannes Wallmeroth and two anonymous referees for valuable comments and suggestions. We also thank seminar participants at the 2015 AAWE, EUAWE and EFMA annual conferences as well as at the Emerging Markets Review Conference on alternative investments for helpful comments. We are responsible for all remaining errors.

${ }^{1}$ Ecole hôtelière de Lausanne, HES-SO // University of Applied Sciences Western Switzerland \& Bordeaux Wine Economics, Route de Cojonnex 18, 1000 Lausanne 25, Switzerland. Telephone: +41 21785 1478; E-mail: philippe.masset@ehl.ch, jean-philippe.weisskopf@ehl.ch (corresponding author).

2 INSIGNIS, LAREFI \& Bordeaux Wine Economics, 19 Quai de Bacalan, 33070 Bordeaux, France. E-mail: bfaye@inseec.com, elefur@inseec.com. 


\section{Introduction}

Fine wine from Bordeaux, a product that two decades ago was virtually unknown to all but some of the Chinese ${ }^{1}$ population, has become fashionable and much discussed from Hong Kong to Beijing. ${ }^{2}$ The discovery of signature molecules in pottery jars in Jiahu dating back 5'000 years suggests that alcohol fermentation has a longstanding practice in China (McGovern, 2009). While traditionally most wines consisted of grains such as rice or millet, grape wine has seen a rapid ascent in recent years. The increase in wine consumption has catapulted China into one of the most coveted markets for wine exporting countries. Since 2000, China has seen an increase from 4.9 million USD in bottled wine imports to 1.3 billion USD by 2011 (OIV, 2014). Today, China and Hong Kong are also the most important customers for Bordeaux wines. China is the largest importer of Bordeaux wines representing $20 \%$ in volume and $17 \%$ in value of all Bordeaux exports. Hong Kong, on the other hand, has positioned itself as the number one place for fine wine from Bordeaux representing 5\% in volume and 18\% in value of all Bordeaux exports in 2011 (Le Monde, 2012). It has further positioned itself as the fine wine gateway to China with a $82 \%$ re-exportation rate of French wines to mainland China (Beaujard, 2014).

Several factors are responsible for the intensified interest in fine wine and the increase in fine wine consumption in China. An increased economic and political openness has led the population to adopt traits from Western lifestyles. At the same time, Chinese government policies have altered consumer behaviour by favouring healthier red wine consumption as opposed to traditional rice wine. Finally, a better education and stronger income has led to the emergence of a newly educated and wealthy class which is fond of fine wine (Sun, 2009). Furthermore, fine wine has not only grown into a popular consumption good but has also turned into a gift of predilection and an alternative investment among wealthy Chinese. According to Forbes magazine, wealth held by the 100 richest Chinese totalled 376 billion USD in 2014 which constitutes an increase of $121 \%$ since 2009. Over the same period, the number of millionaires rose by $189 \%$ to 2.4 million inhabitants. This strongly growing affluent class has discovered luxury goods and collectibles as a mean to differentiate itself and to convey its new status to the outside world. It thus favours prestigious objects such as iconic Bordeaux wines and has led Chinese and Hong Kongese (Ultra) High Net

\footnotetext{
1 Throughout the paper the term China and Chinese refers not only to the People's Republic of China but also to the Special Administrative Regions of Hong Kong and Macau.

${ }^{2}$ The title of this paper is inspired by the film "Red obsession" by David Roach and Warwick Ross on the position of Bordeaux wines in China.
} 
Worth Individuals to put $17 \%$ respectively $14 \%$ of their total wealth into collectibles in form of jewellery, art, precious metals and fine wine (Barclays, 2012).

The wine market caters to different customers and their needs and thus ranges from relatively cheap bulk wine for everyday consumption and which can be found in most supermarkets to fine wine that is more expensive and rare to source. In this paper and in line with literature on wine, we concentrate on fine wine which displays specific features. It foremost has to display a secondary market, typically auctions, on which the bottles can be exchanged after their initial release (Masset and Weisskopf, 2013). For a wine to appear repeatedly on the secondary market it should ideally present three criteria: it should have the ability to improve in bottle and thus show an important aging potential; it should emanate from a well-known wine-growing region and have a long standing history and reputation; it should have been awarded high scores by experts (especially Robert Parker) or be high-standing in an official classification. Overall, this favours the most iconic Bordeaux wines. ${ }^{3}$ Especially the most iconic wines from the Medoc, Pomerol and St. Emilion have established a strong reputation over the last century, are at the top of their respective official classifications and are continuously well-rated by different experts. The fine wine universe thus becomes relatively narrow. According to Milner (2011) investable fine wines are restricted to the 25 best Bordeaux wines and a minority of wines from other regions. He further indicates that 95\% of Liv-ex ${ }^{4}$ turnover is from Bordeaux wines and more than half of it is concentrated on the five first growths of the Medoc. Masset and Weisskopf (2015) confirm that wine funds predominantly invest in the most iconic Bordeaux wines. We, therefore, believe that analysing these prestigious wines from Bordeaux correctly represents the world market for investable fine wine.

In this paper, we first describe the interest of Chinese for fine wine from Bordeaux across the last decade and the concurrent evolution of Hong Kong into the major place for wine auctions. We show that the demand for Bordeaux fine wines has strongly increased over the last decade and that the abolition of excise duties in Hong Kong has favoured the creation of a fine wine hub catering for the growing Chinese demand. We then construct fine wine indices over the period 2007-2014 using a hedonic pricing approach and hammer prices from five global auction houses over the fourteen most iconic Bordeaux wines. The resulting indices are used to examine the existence and evolution of a fine wine price premium at Hong Kong auctions. We find a 19\% premium for fine wine sold at Hong Kong auctions as compared to other auction locations. We argue that the emergence of the premium is the outcome of a strong demand and the specificities

\footnotetext{
${ }^{3}$ Appendix 1 gives a graphical overview of the Bordeaux region and appendix 2 an introduction on some of the important characteristics of the Bordeaux fine wine market.

${ }^{4}$ The London International Vintage Exchange (Liv-ex) is an internet-based trading platform for fine wine that was founded in 1999. It has established itself as the premier source for wine trading and indices.
} 
of the fine wine market. The strong latent demand for fine wine in China and Hong Kong has been coupled with certain difficulties in sourcing these wines at the beginning of the millennium. The opening of the market in Hong Kong and the reduction in excise duties in 2008 has created the opportunity for Chinese consumers and investors to more easily source these fine wines. This has led to a sudden surge in demand for these wines in Hong Kong. At the same time, fine wine buyers trade an emotional asset on a segmented market with different auction places and facing information asymmetries and high transaction costs. Wine prices thus can vary relatively strongly from one auction place to another over longer time periods without reaching an identical price. We further show evidence that the price premium is not uniform across wines. The premium is strongest for wines with the largest brand power or the best expert scores at levels between 20 and $25 \%$. We attribute this phenomenon to the relative inexperience of market participants. Buyers have entered the market by purchasing those wines that have been most advertised or that deliver outstanding quality as evidenced by perfect expert scores. This is reinforced by a wish to convey a signal of status and refinement that is most easily reached by buying the most visible wines. Finally, we observe that the premium has been declining over time from $60 \%$ in 2008 to a stable level of around $15 \%$ since 2012. We argue that this is mainly due to the closing of the educational gap that leads buyers to consider a wider range of possible wine purchases. This is coupled to a clamp down on ostentatious behaviour and anti-corruption measures by the government and the appearance of fake wine bottles that has reduced demand for specific iconic wines.

Our article contributes to literature across several dimensions. First, this article sheds new light on price dynamics of real assets. Evidence on real assets such as collectibles (including fine wine) is limited, but has increased over the last decade. The fine wine literature thus far has characterised the price dynamics from a limited perspective by analysing single auction houses and markets. We thus have indications on wine and auction characteristics influencing wine prices and auction results. However, we do not have evidence on the importance of auction places and their interconnections which gives us indications on the price dynamics on a possibly segmented market. Second, our study extends our understanding of the influence emerging markets, and especially China, have on alternative investments. It is not the first study on collectibles in emerging markets. For instance, Kräussl and Logher (2010) or Kräussl (2014) have studied the performance of art in emerging countries while Vosilov (2015) globally analyses the market for sculptures. Toulan (2002) has examined the impact of market liberalization on company resources for the Argentinean market which also included wineries. However, it is, to the best of our knowledge, the first to consider investments in fine wine from an emerging markets perspective. Mainly due to data constraints, wine economics literature has thus far concentrated on a US (e.g. Sanning et al. (2008) or Masset 
and Weisskopf (2010)) or Australian investor's perspective (e.g. Byron and Ashenfelter (1995) or Fogarty (2006)) and has completely neglected wine investments from an emerging market viewpoint. These latter markets, however, constitute an important aspect as many fine wine producers are entering or evaluating Asian markets as they believe these to have the most potential. Third, it examines the creation and evolution of a price premium of an alternative and emotional asset in an emerging market. This enables us to evaluate how the new and strongly growing demand for an asset can create price distortions on imperfect markets. After several years of continuing strong demand, we believe to have enough data to correctly evaluate price distortion effects resulting from an information acquisition process in an emerging market. Fourth, unlike previous papers, we use a much deeper and more comprehensive dataset. So far the very vast majority of studies have concentrated on a single auction house and location. In this study we expand the geographical reach by analysing different market places in Asia, Europe and North America. We also make use of data emanating from five global auction houses that dominate the market for fine wine auctions.

The remainder of this paper is structured as follows. The next section reviews the literature on wine investments. Section 3 describes the specificities of the Chinese market for fine wine and of auctions in Hong Kong. Section 4 specifies our hypotheses and section 5 the data. Section 6 describes the methodology while section 7 reports results. The final section concludes.

\section{Wine as an investment}

The first studies on the performance of the wine market concentrate on risk and returns of fine Bordeaux wines from a US perspective over the 1970s. The first in-depth study on red Bordeaux wines by Krasker (1979) finds that wine does not perform significantly better than a US risk-free asset over the period 1973-1977. In a follow-up study, Jaeger (1981) extends Krasker's sample period and reduces storage costs and observes that wine performs $16.6 \%$ better than US Treasurybills. Di Vittorio and Ginsburgh (1996) analyse the price evolution of Medoc wines from a US perspective and the characteristics driving wine auction prices. They indicate that while wine prices went up by 75\% between 1981 and 1985, they went down by 15\% between 1985 and 1992. The most important characteristics influencing wine prices are related to climatic conditions during the wine growing season and wine expert ratings. These results are confirmed by Jones and 
Storchmann (2001) who find that climate, Parker ratings, ageing of wine and scarcity all influence the quality and consequently the prices of Bordeaux wines on the US market. ${ }^{5}$

For the period 1986 to 1996, Burton and Jacobsen (2001) analyse red Bordeaux wines which provided a return of $7.9 \%$ p.a. over the period as compared to $13.5 \%$ for US stocks and $5.8 \%$ for US Treasury bonds. This poor result is further reduced by the presence of insurance and storage costs, liquidity issues and the difficulty to obtain some wines. Fogarty (2007) argues that wine returns have been understated in previous papers due to three aspects. First, investors can identify and will invest in quality wines and vintages and not in poor vintages (these are however included in most studies). This corroborates evidence on the influence of climate and expert ratings as described above. Second, investors are interested in after-tax profits. Wine investments are taxexempt in several countries which constitutes a reduction in costs. For financial assets such as bonds and stocks, on the other hand, taxation is non-negligible. Third, risk-return profiles should not be compared pair-wise but as part of a financial portfolio. As most investors hold different assets, the benefits of adding wine to a portfolio and its impact on portfolio risk and return should be analysed.

First evidence of wine in a US investor's portfolio was published by Sanning et al. (2008). They study the risk-return relation for equities and Bordeaux wines. In line with other studies, they observe that wine outperforms stocks and only has a low exposure to market risk factors which is beneficial in terms of portfolio diversification. Masset and Henderson (2010) extend Sanning et al.'s study and find that average returns and volatility are attractive for Bordeaux wines. However, the results strongly depend on vintage, rating and ranking of the wine. In a portfolio framework evidence suggests that Bordeaux wines are relatively uncorrelated with stock markets and should therefore be included in a portfolio. Kourtis et al. (2012) study wines from different world regions and confirm results with correlations offering significant diversification benefits to investors. Masset and Weisskopf (2010) show that wine from different French, Italian and US wine regions outperformed the US stock market while displaying a lower volatility. At the same time, wine generates positive alphas and lower betas in a CAPM framework. Focusing on the economic crisis of 2001-03 and the financial crisis of 2007-09, results are even more favourable for wine. Looking at a conditional CAPM framework, alphas and betas are shown to be time-varying. Though wine is not correlated to equity markets, it is affected by the economy. In a final step, Masset and Weisskopf analyse the impact of wine on portfolio performance. The inclusion of wine is beneficial

\footnotetext{
${ }^{5}$ Several studies have looked in more detail at the influence of different characteristics on wine prices. See for example, Ashenfelter et al. (1995) for the impact of climate, Cardebat et al. (2014) and Masset et al. (2015) for the influence of experts and ranking or Hadj Ali et al. (2008) for Robert Parker's influence. Finally, Storchmann (2012) gives a good overview of the wine economics field and its advances thus far.
} 
for a financial portfolio. Once again this is most pronounced during crises. Recently, Fogarty and Sadler (2014) caution investors on the true benefits of wine for portfolio diversification purposes. They argue that benefits may be spurious depending on the index construction and diversification measurement methodology employed. In a recent article, Masset et al. (2016) show that the lack of liquidity of fine wines needs to be taken into account in order to avoid overstating the performance of this asset class. In particular, their results demonstrate that a substantial part of fine wine returns can be explained by an exposure to market and liquidity risk. Dimson et al. (2015) study fine wine returns over more than a century. They observe that fine wine has yielded a similar return to US stocks of around $5.3 \%$ per year. Considering transaction and insurance costs, wine returns decrease to $4.1 \%$ and thus underperforms equity. Therefore, fine wine yields returns close to those from equities and higher than those from other collectibles. Their findings further indicate that wine correlates positively with stocks using a total beta approach. This stands in contradiction with Sanning et al. (2008), and is explained by the use of a long time period and yearly instead of monthly returns.

\section{The place of Hong-Kong and China on the wine market}

\subsection{China and fine wine - a turbulent affair}

The discovery of tartaric acid in amphorae dating back 5000 years, gives evidence that the history of alcohol fermentation is ancient in China (McGovern, 2009). Its importance has, however, had ups and downs through successive dynasties. First grape viticulture dates back to the Han dynasty (206BC - 220AD) and was brought back from Central Asia to the attention of the Emperor who started large scale cultivations (Black, 2006). Wine quickly became a favoured consumption good, was offered at shrines and used for celebratory occasions (Nishijama, 1986). After the Han dynasty, grape wine fell into oblivion and only resurfaced 400 years later during the Tang dynasty (618907AD). It was once again the emperor (Tang Tai Zong) that took up wine making practices from Western provinces leading to a renewed enjoyment of wine (Zhengping, 2011). Over the next millennium the popularity of wine continued to vanish and resurface to finally re-establish itself as a European import in the late $19^{\text {th }}$ century. 1892 marks the beginning of the modern Chinese wine industry with the establishment of China's first modern vineyard under the name of Zhang $\mathrm{Yu}$ Wine Company which continues to exist until today. After the foundation of the People's Republic of China the wine industry witnessed a decrease in interest once again. Large scale production and wine consumption only slowly picked up again in the 1970s with the launch of the Economic Reforms and the opening towards outside countries. 
Over the last two decades, the traditional consumption of rice and millet wine has slowly been substituted by red wine as favoured beverage. This shift can be attributed to the positive health connotation of grape wine in China (Deadman (2005); Lee (2009)) and the decision of the Chinese government to favour wine to safe keep grain for food production (Thorpe, 2009). Wine colour and taste is an important purchase criterion (Balestrini and Gamble, 2006). Chinese consumers dislike strong, bitter or acid tastes which explain the predominance of red wines $(85 \%$ of the market) over white wines (Dewald, 2003). Furthermore, the colour red is considered as a sign of celebration and happiness in the Chinese culture (Liu and Murphy, 2007). This has led to a strong position for red grape wines. Following an increase in consumption of $175 \%$ to 1.87 billion bottles between 2005 and 2013 China has become the world leader in red wine consumption, ahead of France and Italy (OIV, 2014) and is far ahead of any other Asian market (Anderson and Wittwer, 2013).

The accession of China to the WTO in 2005 has spurred imports of wine due to a decrease from $43 \%$ to $14 \%$ in custom duties. Economic factors, such as the rural exodus with its ensuing access to more expensive goods, or the increase in wealth has spurred fine wine consumption. The interest and enjoyment of foreign wines has become especially prominent in the largest cities (Shanghai, Beijing, Shenzhen, Guangzhou or Hong Kong) in which a mix of expatriates, westerneducated Chinese and curious population can be found (Mitry et al. (2009); Lee (2009)). The relatively new curiosity in fine wine has led to a vacuum in wine knowledge which has made packaging, labelling and marketing efforts key to successfully selling wines. This has strongly favoured and consolidated the position of Bordeaux fine wines in China. Their producers (especially Lafite) were some of the first to enter the Chinese market at the beginning of the 1990s and with the help of French wine exporting associations have managed to cement their reputation and position as wine of predilection. As a consequence, imports of wine bottles have risen by more than $400 \%$ to 289 million litres over the period 2008 to 2013 with France accounting for a market share of around 53\% (Geffroy, 2014).

Alcohol purchase and consumption at social or business events or as gifts is ancient, and culturally grounded (Liu and Murphy, 2007). The serving of prestigious wines at events is considered a mark of respect and generosity towards guests and conveys a signal of prosperity and status (Balestrini and Gamble (2006); Somogyi et al. (2011)) which both are at the core of Chinese culture. Thus, Chinese consumers are primarily seeking wine purchases that are able to convey these two messages. The country of origin of wines consequently becomes an important decision variable. Brand aware Chinese consumers are therefore looking for iconic fine wines that convey a sense of sophistication (Yu et al. (2009); Xu et al. (2014)). Overall, consumption choices of fine 
wine in China is geared towards wines based on colour, brand name and reputation rather than price (Camillo (2012); Liu and Murphy (2007)). This has strongly favoured sales of Bordeaux fine wines over the last decade. Recently, however, consumption patterns have started to evolve based on an increase in wine knowledge and a willingness to discover other wine regions. For example, fine wines from Burgundy and Italy have enjoyed increased popularity with their respective market shares growing from $1.2 \%$ to $6.8 \%$ and $0.9 \%$ to $3.3 \%$ between 2010 and 2013 . However, both remain far behind fine Bordeaux wines with a market share of 83\% in 2013 (Tsang, 2013).

\subsection{Hong Kong - the gateway to China}

The emergence of Hong Kong as the Asian marketplace for fine wine and wine auctions can be traced back to the abolition of excise duties on wine in February 2008. Soon after these regulatory changes, all major auction houses started to open subsidiaries and to conduct wine auctions in Hong Kong. Acker Merrall \& Condit, Christies, Bonham's and Zachys all initiated wine auctions in 2008, followed by Sotheby's in 2009. Hong Kong has quickly established itself as a major venue for wine auctions representing a 11\% market share in 2008 and becoming in 2010 the largest place for wine auctions totalling a global market share of $48 \%$ and a turnover of 165 million USD.

The Hong Kong auction market has not only grown in size but has also gained in maturity and expertise. It has been able to attract some rare wine collections (such as the cellar of the El Bulli restaurant in 2012) and has consistently been able to sell $100 \%$ or close to $100 \%$ of proposed lots. It thus has been able to fetch some of the highest sales prices. As an example, during an auction in 2010 more than 2'000 bottles of Lafite Rothschild emanating directly from the Chateau were sold by Sotheby's in Hong Kong. At the same auction three bottles of Lafite 1869 were bought by an unnamed Asian investor for HKD 1.8 million (or USD 233’000) each (Goldberg, 2010). This example and other evidence on Hong Kong wine auctions illustrate the passion Asian customers have shown for fine wine in recent years. This has led Asians and especially Chinese to be almost the sole buyers at Hong Kong wine auctions. For example, in 2013, 99\% of all lots sold by Sotheby's in Hong Kong went to Asian customers (Lister, 2014). This circumstance is further evidenced by a $82 \%$ re-exportation rate of French wines from Hong Kong to China (Beaujard, 2014). The wine trade with China has been further facilitated by simplified customs rulings with Shenzen in 2010 .

Hong Kong is, however, not only of importance for sourcing fine wine but also works as an opinion leader for large cities in mainland China. Hong Kong shares many similarities with China but has had a longer wine consumption history. It has the largest wine consumption per capita in Asia and due to its central location has established itself as the Asian hub for wine expositions 
(such as Vinexpo) and wine education. Growing Chinese visitor numbers have increased wine sales as travellers bring back wine bottles to China and make Chinese tourists face better wine education and choices. Hong Kong has further constructed a premium image for fine wines as purchasing in Hong Kong has a luxurious image for products that are not widely available in China. It was, for example, a Hong Kong company (Remy Fine Wine) that introduced Lafite Rothschild to mainland China over 20 years ago.

\section{Hypotheses}

Based on the evidence on the market for fine wine, we derive three hypotheses that intend to analyse the influence the high Chinese demand and the specificities of the market have on Hong Kong auction prices.

Hong Kong wine auctions have strongly gained in size and attraction since 2008 as a response to the strong latent demand for fine wine in China. Hong Kong is the natural gateway for these consumers due to its local proximity and the lower language barriers. Second, some producers have catered for the Chinese market by issuing special labels (Lafite Rothschild added the lucky symbol for 8 on some of its bottles) or launching marketing campaigns that have attracted wine buyers to purchase their wines in Hong Kong. Third, the abolition of excise duties has rendered the sale and purchase of wines in Hong Kong very attractive. At the same time, the fragmentation and high transaction costs on this market allow some market locations to display higher prices over a considerable time period as arbitrageurs cannot take advantage of the price discrepancies and thus prices cannot converge. This strong demand from Chinese consumers and the difficulty of uniform pricing on the market for fine wine have driven prices on the Hong Kong auction market upwards and decoupled them from those on other markets. We therefore hypothesise that

Hypothesis 1: fine wine sold at Hong Kong wine auctions commands a premium as compared to other auction places.

Consumers on most Asian markets have only recently discovered fine wine and are thus relatively uneducated in this respect. This leads to a herding effect of customers to purchase wines that display the largest brand power and to ignore wines that are less renowned. Bordeaux producers have been very reactive and have been the first to offer specific labelling and marketing campaigns geared towards their Chinese customers. This is coupled with the importance of Chinese customers to convey a sign of refinement and status that makes the most iconic wines the choice of predilection. For example, Lafite Rothschild has been regarded as the most popular wine in 
China. The reasons for its success range from its rank as first growth in the 1855 Bordeaux classification, consistent good expert scores, good marketing efforts by the producer to the easiness to pronounce its name (Robinson, 2008). We therefore posit that

Hypothesis 2: the Hong Kong premium is stronger for higher rated and visible wines.

This hypothesis is further split into two sub-hypotheses:

- Hypothesis 2a: the Hong Kong premium is stronger the higher the expert score of a wine.

- Hypothesis 2b: the Hong Kong premium is stronger the higher the brand power of a wine.

Over the last few years consumers have started to educate themselves in terms of fine wine which has led to an increase in the number of wine tasting courses and publications geared towards Chinese customers. This has not only led consumers to open up to other wine growing regions such as Burgundy, Italy or the new world but also to be more critical about their Bordeaux purchases. The coupling of inflated prices and the massive counterfeit of iconic Bordeaux wines have gradually modified habits. Many consumers do not want to be perceived as overpaying for a bottle of wine that ends up being a fake (Jones, 2013). Moreover, the anti-corruption campaign initiated by President Xi Jinping has led to a decrease in demand for the most visible wines. Both situations have made customers shift their purchases from the most iconic wines to other producers and wines. At the same time, the economic environment in Europe and the United States has stabilised and improved since 2009. This has had a positive influence on wine demand and prices on US and European auctions. We therefore argue that

Hypothesis 3: the Hong Kong premium has declined over time.

\section{$5 \quad$ Data}

The primary purpose of this study is to complement prior evidence on wine investments by studying the impact Chinese demand has had on the fine wine market. That is, we focus our attention on fourteen Bordeaux fine wines ${ }^{6}$ and consider vintages from 1945 to 2009. These wines are among the finest and most sought-after in the world. Collectors, investors and wine funds allocate a substantial part of their portfolio into these wines. According to Liv-ex, they account for more than $80 \%$ of the fine wine market. Furthermore, the Liv-ex 50 index, a major wine index,

\footnotetext{
${ }^{6}$ These wines include Angelus, Ausone, Cheval Blanc, Haut Brion, Lafite Rothschild, Lafleur, Latour, Margaux, Mission Haut Brion, Mouton Rothschild, Pavie, Petrus, Le Pin, Yquem.
} 
tracks the evolution of these wines only. Similarly, more than $50 \%$ of the components of the Livex 100 index (the "industry's leading benchmark") are made of these wines.

\subsection{Presentation of the dataset}

Our dataset includes all auction hammer prices between January 2007 and November 2014 for the 5 major global auction houses present in Hong Kong and on other auction places in the world. ${ }^{7}$ Our sample, consequently, encompasses 869,029 bottles (only 0.751 ) valued at 707 million USD for 94,494 lots. ${ }^{8}$ The hammer price does not include sales taxes or VAT but contains the respective buyers' premium. Finally, we restrict our dataset to lots containing identical wines as prices cannot be estimated for heterogeneous lots consisting of different producers and vintages.

Our final sample covers 14 producers over 56 vintages for a total of 711 unique wines. We further use scores by Robert Parker, who is considered the best-known wine taster, to take differences in quality amongst different producers and vintages into account. For instance, in the Pomerol appellation, vintage 1998 was considered extraordinary with an average score of 96 points while 1999 was more demanding and barely above average yielding a score of 88 points. The example of two wines from the dataset further illustrates the impact a vintage has on wine prices and scores. Petrus 1998 and Petrus 1999, while being produced by the same château, are qualitatively different wines selling for different prices. In 2013, 27 lots of Petrus 1998 (score of 98) were sold for a median price of 3,267 USD while for Petrus 1999 (score of 94) only 21 transactions occurred for a median price of 1,793 USD. We have score information for 92,160 transactions (representing $97.5 \%$ of all transactions).

We further have information on the number of bottles in a lot and whether they are in their original wooden case. The number of bottles is an important piece of information as it may influence the selling price due to an imbalance of supply and demand. Bottles in an original wooden case (OWC) should sell at a higher price as it lowers the uncertainty on storage conditions and reduces the risk of buying a counterfeit wine.

\subsection{Descriptive statistics}

In Table 1, we report different summary statistics per château. We indicate the average and median price, the number of lots sold, the turnover, the average lot size and Parker score and the

\footnotetext{
7 Acker Merrall \& Condit (New York, Hong Kong), Christie's (New York, London, Hong Kong, Los Angeles, Paris, Amsterdam, Bordeaux, Chicago, Geneva, South Kensington), Sotheby's (New York, London, Hong Kong), Zachy's (New York, Hong Kong, Los Angeles, Las Vegas), Bonham’s (London, Hong Kong).

${ }^{8}$ Major auction houses normally quote the wines in their catalogue and in the results list in local currency. In this paper, we have used USD translated hammer prices to enable the comparison.
} 
presence of an original wooden case for Hong Kong auctions and worldwide auctions ex-Hong Kong. This table illustrates several interesting specificities. These fine wines trade at prices that are high but not necessarily uniform. We see a hierarchy with Le Pin and Petrus from Pomerol being the most expensive wines due to their relative scarcity on the market. These are followed by the first growths of the Medoc such as Lafite Rothschild or Latour. We also find that all wines, but Yquem and Lafleur, trade at statistically higher prices in Hong Kong than in the rest of the world with an average premium of around $40 \%$. Average prices are visibly higher than median prices suggesting that some wines have fetched particularly high prices.

$<$ Insert Table 1 here $>$

Hong Kong represents $30 \%$ of all trades but $45 \%$ of total turnover at wine auctions once again suggesting that wines in Hong Kong were on average sold for higher prices. Lafite Rothschild and Mouton Rothschild are the most traded at auctions in Hong Kong and in the world and represent together a third of the market. This is due to the larger number of bottles produced at Mouton Rothschild and the strong popularity of Lafite Rothschild over the period. Turnover figures show that Lafite Rothschild, Mouton Rothschild and Petrus have shown the highest sales accounting for more than $50 \%$ of total turnover. Furthermore, Lafite Rothschild has seen a large surge in demand in Hong Kong with its turnover there being as high as in the rest of the world. The wines sold in Hong Kong generally display higher Parker scores which may be attributed to the sale of relatively younger wines on this market which profited from an inflation of good scores in recent years due to some very good vintages. Lot size also appears to be slightly higher in Hong Kong which is mainly explained by the higher percentage of wines sold in their original wooden cases.

Table 2 shows the same summary statistics as in Table 1 but per vintage for Hong Kong auctions and for worldwide auctions ex-Hong Kong. Overall, results are very much in line with those observed in Table 1. The turnover and number of sold lots demonstrate that some vintages, such as 1982 or 2000 attract more interest from collectors and investors than others, such as 1981 or 1999. This is mostly due to differences in quality. Other exceptional vintages include 1945 (excellent and also highly symbolic as it corresponds to the end of WWII), 1959, 1961 and, more recently, 1990, 2005, 2009 and 2010. These vintages of outstanding quality also trigger higher median prices. For instance, the price for a bottle of 1945 or 1947 was above 2,000 USD, while wines from 1980 or 1984 traded on average for less than 250 USD. 
$<$ Insert Table 2 here $>$

Turning to Hong Kong we find that every single vintage yielded a premium as compared to the rest of the world and that for about $2 / 3$ of the vintages these are significant. It was thus possible to sell these wines at a higher price on the Hong Kong market. Evidence also suggests that turnover and number of lots per vintage is relatively similar in Hong Kong as compared to other auction locations. The best vintages were again sold the most but turnover for more recent vintages (20032009) were slightly higher in Hong Kong but similar or slightly lower for all other vintages. This indicates that Hong Kong customers were relatively more attracted by recent vintages. Wines purchased by Hong Kong customers are on average slightly younger than those auctioned on other continents. The average Parker score, lot size and presence of an original wooden case were also higher in Hong Kong than on other continents.

Table $3 \mathrm{a}$ shows the average and median price, the number of observations and the turnover for each auction house and location. We observe that the importance of the different auction houses depends on the location. Christie's and Sothebys dominate the European market and account for nearly a quarter of worldwide turnover. In the United States, competition is more dispersed with Zachy's and Acker Merrall \& Condit being largest followed by Christie's and Sothebys. On the Hong Kong market it is especially Acker Merrall \& Condit and Sothebys that dominate with Christies and Zachy's being slightly smaller. In Europe and Hong Kong Bonham's has established itself as a boutique auction house that is smaller than the classic four wine auction houses. We further find that median prices were highest in Hong Kong followed by North America and Europe and that the Hong Kong market displayed a 45\% market share by turnover.

$<$ Insert Table $3 \mathrm{a}$ and $3 \mathrm{~b}$ here $>$

Turning to the sample period we find that the Hong Kong market evolved from inexistence in 2007 to the largest market with a 60\% market share by 2011. Prices also varied depending on the year in the sample period. On all three markets we evidence highest prices realised in 2010 and 2011 followed by a decline over the remaining 3 years. We further observe that in the United States Acker Merrall \& Condit and in Asia Christie's and Acker Merrall \& Condit yielded the highest median prices. In Europe, the three auction houses alternately led to highest prices. A premium at Hong Kong auctions is present for each auction house but varies depending on the auction house. 
Interestingly, only Christie's and Acker Merrall \& Condit yield significantly higher prices in Hong Kong while Sotheby's or Zachy's are only partially able to trigger this premium and Bonham's not at all. This observation can be explained in two ways. A true auction house effect may exist in which some auction houses are able to trigger price premiums in some locations while others cannot. Second, the wine basket sold in Hong Kong may differ from other auction places or from one auction house to another. Finally, it appears that wines sold in Europe yield a discount as compared to both Hong Kong and the United States.

Table $3 \mathrm{~b}$ shows the average lot size, Parker score and presence of an original wooden case per auction house, year of sale and auction place. Once again wines sold in Hong Kong display slightly better Parker scores than those sold in Europe or the United States. This may explain a portion of the price differential observed in Table 3a. Lot size is higher and original wooden cases more prominent in Hong Kong. The explanation lies in the relatively younger vintages exchanged in Hong Kong and a willingness by auction houses to sell particularly interesting lots in Hong Kong. Overall, we find a somewhat different profile for lots exchanged in Hong Kong which may partly explain the price premium observed in Table 2 and calls for a robust estimation method such as the hedonic pricing model which may take these differences into account.

$<$ Insert Table 4 here $>$

Table 4 presents descriptive statistics and correlation coefficients for Parker scores, lot size and wine prices. Parker scores average 94.2 points and are mostly situated between 90 and 100 points with a few lower scores and none above 100 (per definition) which leads to a negative skewness. Lot size averages around 9 bottles a lot, but with a predominance of lots in original wooden cases (12 bottles) and some rare but very large lots. This leads to a positive skewness and high kurtosis. The average price per bottle is close to 1,000 USD but with some large variability. The log(price), on the other hand, represents classic normal distribution characteristics with a skewness close to zero and a kurtosis close to 3 .

The correlations are in line with expectations. A large lot leads to a price discount while a higher Parker score yields a price premium. The correlation between score and lot size, while significant, is close to zero showing independence between the two variables. Overall, descriptive statistics suggest that our approach is solid with a dependent variable following a normal distribution and explanatory variables being essentially uncorrelated amongst each other. 


\section{$6 \quad$ Methodology}

Fine wine is different from stocks, bonds or other asset classes. It does not have any cash-flows and trades on a complex, fragmented and illiquid market. Consequently, most wines are not exchanged regularly at auctions. These features need to be accounted for, or else they may induce biases in index construction.

Wine indices can be constructed in multiple ways. The composite index technique, which uses weighted average wine prices is favoured in practice due to its simplicity. In academia, authors tend to choose between hedonic regressions (see Jones and Storchmann (2001) and Fogarty (2006)) or repeat-sales regressions (see Burton and Jacobsen (2001), Masset and Weisskopf (2010), Dimson et al. (2015)). The two approaches deal with the heterogeneity of the traded wines and the lack of liquidity on the wine market.

In the present study, we use the hedonic regression approach as it uses all observations (not only repeat-sales transactions) and controls for a variety of wine and transaction-specific attributes influencing auction prices. Our sample, composed of relatively liquid and homogeneous wines, ensures that the number of observations per explanatory variable is high and leads to an unbiased outcome. This approach follows the assumption that the price of a bottle of wine depends on its attributes and the implicit value attached to each of them. The generic form of our hedonic regression for a specific lot $i$ is:

$$
p_{i}=\beta_{0}+\sum_{j=1}^{J} x_{i j} \beta_{j}+\varepsilon_{i}
$$

Where $p_{i}$ is the natural logarithm of the price of lot $i=\{1,2, \ldots, N\} ; X$ is a matrix, whose row $i$ contains information about the attributes of lot $i$. These characteristics contain indicators such as the name of the producer, the vintage and the Robert Parker score, but also the number of bottles in a lot or the existence of an original wooden case. In order to take the temporal evolution

of prices and specificities of auction venues into consideration we extend equation [1] with two matrices of explanatory variables $D$ and $Z$.

$$
p_{i}=\beta_{0}+\sum_{j=1}^{J} x_{i j} \beta_{j}+\sum_{t=1}^{T} D_{i t} \theta_{t}+\sum_{k=1}^{K} Z_{i k} \gamma_{k}+\varepsilon_{i}
$$


$D$ is a matrix of dummies, whose row $i$ column $t$ takes the value 1 if wine $i$ has been exchanged in period $t$ and 0 otherwise. The coefficients of this matrix, summarised in vector $\theta$, correspond to the natural logarithm of the index levels at different dates $t=(1, \ldots, T)$. Subsequently, the exponential of these coefficients, $\exp (\hat{\theta})$, where $\hat{\theta}$ are the fitted regression coefficients from [2] can be used to create an index on fine wine prices. $Z$ is a matrix of dummies, whose row $i$ column $k$ takes the value 1 if wine $i$ has been traded at a specific auction house and location and 0 otherwise.

We estimate five specifications using equation [2]. All include a common set of explanatory variables and an interaction term for each specification to verify the three hypotheses. The first specification focuses on the premium for wines sold at Hong Kong auctions and is used to test hypothesis 1 . The second to fourth specifications are more detailed as they assess the influence of expert scores and brand power on the Hong Kong premium. They will be used to test hypothesis 2. Finally, the last specification is used to test the possible decline of the Hong Kong premium as explained in hypothesis 3 . Table 5 contains the list of variables used for each specification. The various variables can be defined as follows:

$<$ Insert Table 5 here $>$

We include variables such as producer, vintage, Robert Parker score, number of bottles and the existence of an OWC. These variables allow us to explain price differences emerging from different wines exchanged at auctions. For example, Ashenfelter et al. (1995) observe wine quality and prices are mainly affected by the climatic conditions prevalent in the Bordeaux region. Likewise, the châteaux dummy allows us to control for natural endowments (soil), wine-making facilities or the individual and collective reputation a producer faces and which affect wine prices (Malter, 2014). In order to account for the quality of each château in a particular vintage, we resort to Robert Parker scores. He is the most followed wine expert by wine aficionados and investors due to his preciseness in tasting wines and the impact his scores and notes have on wine prices (see Jones and Storchmann (2001), Masset et al. (2015)). He uses a range of scores from 50 to 100 points and based on this classifies wines into different categories. Consequently, a wine with scores between 50 and 59 is categorised as avoid, 60-69 denotes below average wines, 70-79 points designate average wines, 80-89 good to excellent wines, 90-95 outstanding wines and finally 96-100 indicate extraordinary wines. Wines with low Parker scores consequently often attract less attention from 
collectors and investors. Throughout the empirical specifications, we use standardised scores ${ }^{9}$ and squared scores to account for a non-linear relationship between scores and prices.

The same wine proposed at the same auction venue may lead to different hammer prices. We therefore include two additional variables in the five specifications. We first add a dummy variable that takes value 1 if the auctioned wine comes in its original wooden case (OWC) and 0 otherwise. The presence of an original wooden case reassures market participants as it diminishes the uncertainty of purchasing a forged wine bottle. The second variable is defined as the number of bottles in a particular lot. This variable controls for the negative relation one would expect between the numbers of bottles auctioned and hammer prices.

Auction attributes should also have an influence on wine prices. Characteristics such as taxes, fees, shipping costs or auction house reputation may explain that wines are exchanged for different prices depending on auction house and location. In order to control for such effects, we include dummies for each of the five auction houses and three locations in the model. We further add dummies for each month over the period January 2007 to November 2014 to construct our indices.

Finally, we add an additional specific variable for specifications 2 to 5 to test our different hypotheses. To test hypothesis 2 we control for the impact wine visibility and quality has on the Hong Kong premium by following three separate specifications. In the first, we add an interaction term between Parker scores on the Hong Kong premium. In the second, we use interaction terms to evaluate the château-specific impact on the premium. In the third, we interact the Hong Kong premium with brand power of a château as indicated by Liv-ex to gauge whether brand visibility influences prices. To test hypothesis 3 we use dummy variables to estimate a time-varying Hong Kong premium in specification 5.

\section{$7 \quad$ Results}

\subsection{Fine wine prices and the Hong Kong premium}

Table 6 reports results on the coefficient estimates of specification 1. Findings are described for all auctions in the world, for the world ex-Hong Kong and solely for Hong Kong. The two subsamples not only indicate that the coefficients and the model are robust but also allow us to obtain more information on the specificities of Hong Kong wine auctions. Over the 14 châteaux we only find Ausone and Lafite Rothschild to have a higher coefficient in Hong Kong than in the rest of

\footnotetext{
${ }^{9}$ We standardise by subtracting the average score from original scores and dividing this by the standard deviation of scores.
} 
the world. Cheval Blanc, Mission Haut Brion and Yquem are relatively cheapest in Hong Kong. The very low coefficient for Yquem can be explained by the aversion of the Chinese palate to sweet wines which makes them difficult to sell. Turning to the coefficients for the different auction houses it appears that globally auction houses are able to sell wines at relatively similar levels with the exception of Bonhams that sells wines at lower prices than its competitors. In Hong Kong, however, Christie's is able to sell wines at higher prices than all other auction houses. This can be due to the higher visibility and reputation of Christie's that is also auctioning other collectibles and has a longstanding history.

$<$ Insert Table 6 here $>$

The other coefficients are in line with previous evidence. The higher the number of bottles per lot the lower the price due to the imbalance of supply and demand. Many more people want to sell a wine but the demand is not absorbing it at a single auction. Wines in their original wooden case sell at higher prices due to a reduced probability of counterfeiting and better storage. Results on Parker scores are also in line with higher Parker showing better quality and thus leading to higher prices on average.

Figure 1 illustrates the vintage effect of fine wine. We take 1945 as reference as it yields the highest prices in the dataset. We observe that 1947 and 1949 have similar prices but that prices for all other vintages show, sometimes significantly, lower levels. We further notice that price levels strongly depend on vintage quality. In line with prior evidence and common perception vintages such as 1959, 1961, 1982, 1989 or more recently 2000, 2005 and 2009 yield high prices. This is due to two phenomena. First, these exceptional vintages are normally sold on the primary market exchâteaux at higher prices than poorer vintages. Second, the aging and reselling potential of these wines are much more pronounced and thus constitute a more interesting purchase for collectors or investors. Finally, we see that price levels are robust irrespective of auction location.

\section{$<$ Insert Figure 1 here >}

Figure 2 tracks the evolution of three wine indices over the sample period. The continuous line takes all observations into account, while the densely dashed line looks at Europe and North America and the more interspersed dashed line at Hong Kong. In general, we observe that the 
wine market displays an upturn between 2007 and the end of 2010 with price levels doubling. Since 2011 prices appear to have turned and show a more negative trend. We also see that Hong Kong auctions appear to be more volatile with four clear peaks during the period. Especially the September 2010 peak is high, showing the strong exuberance on the Hong Kong market around that time. It has also heralded the start of the decline on the fine wine market.

\section{$<$ Insert Figure 2 here $>$}

The total sample used in Table 6 allows us to further test the occurrence and amplitude of a Hong Kong premium on fine wines. We find that over the period 2008-2014 fine wines sold at Hong Kong auctions yielded a significantly positive premium of $19.72 \%(\exp (0.18)-1)$. This confirms hypothesis 1 in which we claim that the latent demand by Chinese customers coupled with the abolition of excise duties in Hong Kong has led this market to become the gateway to China. The lasting existence of this premium over six years further indicates that arbitrageurs were not able to profit from the situation and to make prices converge in the medium-term. The higher intercept in specification 1c for the Hong Kong market further indicates that wines were on average priced more highly on this auction place which further validates hypothesis 1 .

\subsection{Wine visibility and the Hong Kong premium}

Table 7 reports results for specifications 2 to 4. We argue that the Hong Kong premium is not uniform and will depend on the château, wine quality and its brand power. On a relatively new market with consumers who have only a limited background on fine wine it seems natural that buyers try to find indicators to guide their purchases. In a first step, we therefore analyse in more detail the impact Robert Parker has on wine prices. As he is considered the premier authority on Bordeaux wines with a strong track-record since the 1970s he constitutes the premier source for potential buyers wanting a better understanding of which wines to purchase.

In specification 2 we add interaction terms between Parker score categories and the Hong Kong premium to our initial model. The score categories are based on the official categories used by Robert Parker and range from 50-79 points being average to below average to 100 representing perfection. We find a U-shaped relation with the highest premium on wines that either have very low scores (50-89) or a perfect 100 points. The premium for the 100-point wines indicates that buyers put a high price on the symbol of perfection and that owning a 100-point bottle is conveying a strong signal of status. This is reinforced by the lower coefficient for the nearly perfect wines 
with a score of 99 points. For the low scores the lack of wine knowledge may induce buyers to believe that the brand is more important than the quality of a vintage. Knowledgeable buyers will know that, for example, Lafite Rothschild is an excellent wine but also that a poor vintage has an effect on aging potential or on resale value that makes it less worthwhile a purchase. On an emerging market, in which status and signals are more important, buyers will purchase the most prestigious brands and might be satisfied with poorer vintages as they are cheaper but still convey a status signal. This lends support to hypothesis $2 \mathrm{a}$.

$<$ Insert Table 7 here $>$

In a second step, we analyse the impact each château individually has on the Hong Kong premium. Specification 3 therefore adds an interaction term between the Hong Kong premium and each château to the baseline model. We find that Yquem displays a negative coefficient reinforcing the notion that sweet wines have a difficult time selling in China. The most positive premium is found for Lafite and Mouton Rothschild on the left bank and for Ausone and Le Pin on the right bank. For the two Rothschild wines visibility may explain the result. Especially Lafite Rothschild was the first producer to actively advertise its wines in China and has until today a privileged position on this market. For Ausone and Le Pin its scarcity and low transaction volume as evidenced in Table 1 may explain the premium. Overall, it appears that wines that can convey a strong signal of status and refinement are favoured. This is both achieved through the scarcity of a wine or through its visibility on the market and supports hypothesis $2 \mathrm{~b}$.

In a final step, we analyse the influence of brand power on the premium using specification 4 . For this, we interact the Liv-ex Power 100 that annually ranks wines according to their brand power with the Hong Kong premium. We argue that those châteaux with the strongest brand will be most visible and should therefore convey more easily a message of refinement, wealth and status. The negative interaction term indicates that the higher a wine is ranked the higher the premium becomes. This shows that the development of a brand, especially on markets with low product knowledge, is important for producers to increase demand. This strongly favours the sales of Lafite and Mouton Rothschild that display the highest rank but penalises wines such as Cheval Blanc or Lafleur with a relatively low ranking. This validates hypothesis $2 \mathrm{~b}$ that higher visibility leads to a higher premium. 


\subsection{The decline of the Hong Kong premium}

Figure 3 illustrates results of specification 5 in which we add interaction terms between the Hong Kong premium and the time of sale. We further fit a polynomial model of degree 3 to estimate a temporal trend. ${ }^{10}$ We argue that the Hong Kong premium is not uniform across time. First, the economic and financial recovery in Europe and North America has led to higher demand for fine wine on these two continents. Second and more importantly, the Hong Kong market has evolved over the sample period. ${ }^{11}$ It progressed from a market in which fine Bordeaux wines were finding buyers very easily to a market in which buyers become more wine-educated and want to discover new producers and wine regions. Bateman (2014) describes that the thirst for wine in China is driven and matched only by the increasing desire by consumers for wine education. This can take different forms and translates in an increase in demand for programs offered by wineries, distributors, consultants and universities. Schmitt (2012) further notes that, over the period 20092012, the number of participants in WSET ${ }^{12}$ courses has tripled in the Asia-Pacific region, especially due to a surge in interest in China, Hong Kong and Taiwan. By 2012 China has thus become its largest market. Marquis and Yang (2014) and SudOuest.fr (2015) show that the evolving wine palate of existing consumers in China has led to more personal preferences and a shift from label drinkers to a more nuanced attitude towards wine. At the same time, the launch of the anti-corruption campaign by President Xi Jinping has further put a damp on the most conspicuous wine brands. More and more, giving expensive gifts or showing signs of wealth have become challenging for Chinese officials. This is not only true for wines but for all luxury goods and has led many Chinese consumers to drift from the purchase of purely ostentatious goods to an accessible luxury approach which puts more emphasis on lifestyle than pure status (Zakkour, 2014; Zhou, 2015). Anderson and Wittwer (2015) argue that this shift does not influence wine import volumes or domestic production but hits imported values as less super-premium wines are consumed. According to them, France will bear most of this fall. Thus, the demand for the most visible and best-known brands has decreased and moved to wines that are qualitative but not (yet) seen as ostentatious. Finally, the increase in fake bottles of Bordeaux fine wine, especially for Lafite Rothschild, has also had a negative effect on auction results for some wines.

\footnotetext{
10 The polynomial model of degree 3 is used as an example. Results using a model of degree 2 or 4 yield very similar results.

${ }^{11}$ According to the law of supply and demand, the growth in demand for Bordeaux fine wines outside Hong Kong has led to an increase in prices in Europe and the United States. At the same time, the slowdown in demand in Hong Kong has led to a stagnation of prices there. Thus, the average price differential (and the Hong Kong premium) between Hong Kong and other auction places has declined (all other things equal).

12 The Wine and Spirit Education Trust (WSET) has offered education and training in wine and spirits since the 1960s. Today, it is one of the best-known education facilities on the topic worldwide.
} 


\section{$<$ Insert Figure 3 here $>$}

Figure 3 demonstrates that the premium varies through time and displays a very large increase for one Hong Kong auction in October 2010 in which the buyer's frenzy pushed the premium to 90\%. This peak coincides with the very strong and high priced sales of Lafite wines mentioned in section 3.2. The estimated trend gives a clearer idea and shows that the average premium is indeed declining through time in an inverse logarithmic manner. It has strongly declined between 2008 and 2010, the years in which wine auctions were first conducted in Hong Kong and a true frenzy broke out on fine wine in this part of the world and which led to a $60 \%$ premium. It has since 2012 stabilised at a premium of around 15\%. This order of magnitude once again hints at a somewhat higher demand in Hong Kong and China but also at high transaction costs that do not make prices converge and the premium disappear. This confirms hypothesis 3.

\subsection{Robustness tests}

To verify the robustness of the results obtained in the previous sections, a series of tests are performed. ${ }^{13}$ Table 8 describes the motivation underlying each test, the approach used to confirm the initial findings and the robustness results obtained. The tests performed allow us to reduce concerns on outliers biasing index coefficients. It further ensures that specific characteristics of the market are not driving our results. As a consequence, we confirm that the definition of the reference price used in the regressions, the reputation and size of a single auction house or wine age do not affect our findings. We further show that foreign exchange rate fluctuations are not responsible for the Hong Kong premium.

$<$ Insert Table 8 here $>$

\section{Conclusion}

Hemingway wrote that wine "has been brought to the greatest perfection, and it offers a greater range for enjoyment and appreciation than, possibly, any other purely sensory thing". Wine is regarded as an experience good that has to be tasted to be fully appreciated but it is also considered

\footnotetext{
${ }^{13}$ Detailed results are not reported here but are available from authors upon request.
} 
a passion investment whose price has considerably appreciated over the last decade. Both attributes related to the absence of cash-flows leads wine prices to be tributary to the purest form of offer and demand. The latent demand and recent surge in interest for fine wine in China has led to the emergence of new consumers that want to experience wine and invest in their passion. This has had a non-negligible influence on the structure of the wine market and wine prices.

In this paper we have analysed the existence and evolution of a price premium on the Hong Kong auction market as compared to the North American and European markets. Our study is based on an extensive set of auction hammer prices covering Bordeaux fine wines sold over the period 2007-2014 at five different auction houses around the world. Using a hedonic regression approach which relates auction prices to wine attributes we find evidence that wines sold on the Hong Kong market triggered a 19\% premium. We argue that the emergence of the premium is the outcome of a strong latent demand from Chinese customers and the incapacity to conduct arbitrage strategies on the wine market due to its specificities and complexity. Investors thus appear to be stuck with the prices they face in their geographical area. The only possibility to increase returns becomes to identify wines that are not yet reaching their true price appreciation potential. As long as no cheap way of purchasing and transporting wine from one continent to another emergences exploitable arbitrage strategies will also remain scarce. We further show evidence that the price premium is not uniform across wines. The premium is strongest for the most visible wines. We attribute this phenomenon to the relative inexperience of market participants. Buyers have entered the market by purchasing those wines that have been most advertised or that deliver perfect quality due to their high expert ratings. This is reinforced by the wish to convey a signal of status and refinement that is most easily reached by buying the most visible brands or the best graded wines. For producers it is thus important to create a strong visibility and reputation for quality and status on Asian markets. For investors, it appears that indulging in wine picking may yield the best outcome. Going for quality wines from reputable producers and regions with an established brand enhances the probability for future price appreciation. Finally, we observe that the premium is declining over time. We argue that this is mainly due to the closing of the educational gap that leads buyers to consider a wider range of possible wine purchases. This is coupled to a clamp down on ostentatious behaviour and anti-corruption measures by the government and the appearance of fake wine bottles that has reduced demand for specific iconic fine wines. Asian consumer and investors have thus turned from the most reputable and visible wines that were going for very high prices to other wines. While the cultural aspects of Chinese customers remain, these are now more inclined to go for excellent wines from other regions that are qualitative but less ostentatious than first growth from Bordeaux and on which they have gained more information from wine courses 
and websites. This means that investors have to be aware of future wine trends and need to identify those wines that are followers to the most prestigious and visible wines.

All in all, as on many other markets, it is important for a wine investor to know the wine market with all its specificities. The passion and emotions related to wine make it an investment that is difficult to evaluate and fully comprehend. Moreover, due to differences in culture, taste, regulatory environment and education the knowledge obtained on one continent cannot be transferred as such to other market places but has to be analysed in more depth. 


\section{References}

Anderson, K., G. Wittwer, 2013, Modeling Global Wine Markets to 2018: Exchange Rates, Taste Changes, and China's Import Growth. Journal of Wine Economics 8, 131-158.

Anderson, K., G. Wittwer, 2015, Asia's Evolving Role in Global Wine Markets. China Economic Review 35, 1-14.

Ashenfelter, O., D. Ashmore, R. Lalonde, 1995, Bordeaux wine vintage quality and the weather. Chance 8, 7-14.

Balestrini, P., P. Gamble, 2006, Country-of-origin effects on Chinese wine consumers. British Food Journal 108, 396-412.

Barclays, 2012, Profit or Pleasure? Exploring the Motivations Behind Treasure Trends. London: Barclays.

Bateman, J., 2014, How education is driving China's unquenchable thirst for wine. Available at: http://asiancorrespondent.com/118504/how-education-is-driving-chinas-unquenchable-thirstfor-wine/. Accessed 21 September 2015.

Beaujard, C., 2014, Potentiel des vins biologiques en Chine. Paris: Ubifrance.

Black, J., 2006. China - Ancient China, in: Robinson, J. (Ed.), The Oxford Companion to Wine. Oxford: Oxford University Press.

Burton, B.J., J.P. Jacobsen, 2001, The rate of return on investment in wine. Economic Inquiry 39, 337-350.

Byron, R.P., O. Ashenfelter, 1995, Predicting the Quality of an Unborn Grange. Economic Record 71, 40-53.

Camillo, A.A., 2012, A strategic investigation of the determinants of wine consumption in China. International Journal of Wine Business Research 24, 68-92.

Cardebat, J.-M., J.-M. Figuet, E. Paroissien, 2014, Expert opinion and Bordeaux wine prices: An attempt to correct bias in subjective judgements. Journal of Wine Economics 9, 282-303.

Deadman, P., 2005, How to be healthy: traditional Chinese health preservation teachings and modern research. Journal of Chinese Medecine 78, 41-49.

Dewald, B.W.A., 2003, Wine Consumption in Hong Kong. International Journal of Wine Marketing 15, 54-68. 
Di Vittorio, A., V. Ginsburgh, 1996, Pricing red wines of Medoc vintages from 1949 to 1989 at Christie's auctions. Journal de la Société Statistique de Paris 137, 19-49.

Dimson, E., P. Rousseau, C. Spaenjers, 2015, The Price of Wine. Journal of Financial Economics 118, 431-449.

Fogarty, J.J., 2006, The return to Australian fine wine. European Review of Agricultural Economics 33, 542-561.

Fogarty, J.J., 2007, Rethinking wine investment in the UK and Australia. AAWE Working Paper 6. New York: American Association of Wine Economists.

Fogarty, J.J., R. Sadler, 2014, To Save or Savor: A Review of Approaches for Measuring Wine as an Investment. Journal of Wine Economics 9, 225-248.

Geffroy, O., 2014, Vignobles et marché chinois. Lisle sur Tarn: Institut français de la vigne et du vin.

Goldberg, H.G., 2010, Lafite prices spiral at record Sotheby's Hong Kong auction. Decanter. Available at: http://www.decanter.com/news/wine-news/505082/lafite-prices-spiral-at-recordsotheby-s-hong-kong-auction. Accessed 25 november 2014.

Hadj Ali, H., S. Lecocq, M. Visser, 2008, The Impact of Gurus: Parker Grades and En Primeur Wine Prices. Economic Journal 118, F158-F173.

Jaeger, E., 1981, To Save or Savor - the Rate of Return to Storing Wine. Journal of Political Economy 89, 584-592.

Jones, G.V., K.H. Storchmann, 2001, Wine market prices and investment under uncertainty: an econometric model for Bordeaux Crus Classes. Agricultural Economics 26, 115-133.

Jones, T.Y., 2013, In China, fake European wine more worrying than tariffs. Reuters. Available at: http://www.reuters.com/article/2013/06/09/us-china-wine-fakes-

idUSBRE95801Q20130609. Accessed 05 December 2014.

Kourtis, A., R.N. Markellos, D. Psychoyios, 2012, Wine price risk management: International diversification and derivative instruments. International Review of Financial Analysis 22, 30-37.

Krasker, W.S., 1979, Rate of Return to Storing Wines. Journal of Political Economy 87, 13631367.

Kräussl, R., 2014, Art as an Aternative Asset Class: Risk and Return Characteristics of the Middle Eastern \& Northern African Art Markets. University of Luxembourg Law Working Paper No 1410. 
Kräussl, R., R. Logher, 2010, Emerging art markets. Emerging Markets Review 11, 301-318.

Le Monde, 2012, Les vins de Bordeaux atteignent un record à l'export en 2011. Available at: http://www.lemonde.fr/economie/article/2012/03/12/les-vins-de-bordeaux-atteignent-unrecord-a-1-export-en-2011_1656275_3234.html. Accessed 10 December 2014.

Lee, K., 2009, Is a glass of Merlot the symbol of globalization? International Journal of Wine Business Research 21, 258-266.

Lister, E., 2014, New benchmark on the block. The World of Fine Wine. Available at: http://www.worldoffinewine.com/news/new-benchmark-on-the-block-4208094. Accessed 25 november 2014.

Liu, F., J. Murphy, 2007, A qualitative study of Chinese wine consumption and purchasing. International Journal of Wine Business Research 19, 98-113.

Malter, D., 2014, On the Causality and Cause of Returns to Organizational Status Evidence from the Grands Crus Classés of the Médoc. Administrative Science Quarterly 59, 271-300.

Marquis, C., Z. Yang, 2014, The Chinese Wine Market: Vanguard of a Consumption Society. Ithaca: Cornell University.

Masset, P., J.-M. Cardebat, B. Faye, E. Le Fur, 2016, Analyzing the risk of an illiquid asset - The case of fine wine. Working Paper. Lausanne: Ecole hôtelière de Lausanne.

Masset, P., C. Henderson, 2010, Wine as an alternative asset class. Journal of Wine Economics 5, 87-118.

Masset, P., J.-P. Weisskopf, M. Cossutta, 2015, Wine tasters, ratings and en primeur prices. Journal of Wine Economics 10, 75-107.

Masset, P., J.P. Weisskopf, 2010, Raise your glass: Wine investment and the financial crisis. AAWE Working Paper 57. New York: American Association of Wine Economists.

Masset, P., J.P. Weisskopf, 2013. Wine as an Alternative Asset Class, in: Pichery, M.-C., GiraudHéraud, E. (Eds.), Wine Economics: Quantitative Studies and Empirical Applications.

Basingstoke: Palgrave Macmillan.

Masset, P., J.P. Weisskopf, 2015, Wine funds - an alternative turning sour? Journal of Alternative Investments 17, 6-20.

McGovern, P., 2009, Uncorking the Past: The Quest for Wine, Beer, and Other Alcoholic beverages. Berkeley: University of California Press. 
Milner, J., 2011, The Fine Wine Investment Market - An Inside View. Liv-ex. Available at: http://www.blog.liv-ex.com/2011/11/the-fine-wine-investment-market-an-inside-view.html. Accessed 12 december 2014.

Mitry, D., D. Smith, P. Jenster, 2009, China's role in global competition in the wine industry: A new contestant and future trends. International Journal of Wine Research 1, 19-25.

Nishijama, S., 1986. The Economic and Social History of Former Han, in: Twitchett, D., Loewe, M. (Eds.), Cambridge History of China: Volume I: the Ch'in and Han Empires, 221 B.C. - A.D. 220. Cambridge: Cambridge University Press.

OIV, 2014, Le marché du vin: évolutions et tendances. Paris: OIV.

Robinson, J., 2008, The legend of Lafite. Available at: http://www.jancisrobinson.com/articles/the-legend-of-lafite. Accessed 05 December 2014.

Sanning, L., S. Shaffer, J.M. Sharratt, 2008, Bordeaux wine as a financial investment. Journal of Wine Economics 3, 51-71.

Schmitt, P., 2012, Wine education booms in China. Available at: http://www.thedrinksbusiness.com/2012/11/wine-education-booms-in-china/. Accessed 21 September 2015.

Somogyi, S., E. Li, T. Johnson, J. Bruwer, S. Bastian, 2011, The underlying motivations of Chinese wine consumer behaviour. Asia Pacific Journal of Marketing and Logistics 23, 473-485.

Storchmann, K., 2012, Wine Economics. Journal of Wine Economics 7, 1-33.

SudOuest.fr, 2015, Vinexpo: signaux de reprise du marché chinois des vins et spiritueux. Available at: http://www.sudouest.fr/2015/06/17/vinexpo-signaux-de-reprise-du-marchechinois-des-vins-et-spiritueux-1954856-789.php. Accessed 21 September 2015.

Sun, B., 2009, National Wine Market People's Republic of China. U.S. Department of Agriculture, Foreign Agricultural Service Gain Report Number CH9808.

Thorpe, M., 2009, The globalisation of the wine industry: new world, old world and China. China Agricultural Economic Review 1, 301-313.

Toulan, O.N., 2002, A resource perspective on internationalization responses to market liberalization. Emerging Markets Review 3, 51-68.

Tsang, A., 2013, Burgundy and Italy uncork their potential in fine wine market. Financial Times. Available at: http://www.ft.com/intl/cms/s/0/258da5ba-69a8-11e3-aba3-

00144feabdc0.html\#axzz3OoSUvjsv. Accessed 14 january 2015. 
Vosilov, R., 2015, Sculpture as an Alternative Investment: an analysis of price dynamics between sculpture and equity and bond markets. Journal of Alternative Investments 17, 21-45.

Xu, P., Y.C. Zeng, S. Song, T. Lone, 2014, Willingness to pay for red wines in China. Journal of Wine Research 25, 265-280.

Yu, Y., H. Sun, S. Goodman, S. Chen, H. Ma, 2009, Chinese choices: a survey of wine consumers in Beijing. International Journal of Wine Business Research 21, 155-168.

Zakkour, M., 2014, The China Luxury Downturn Is Real - Global Luxury Brands Must Adjust. Forbes. Available at: http://www.forbes.com/sites/michaelzakkour/2014/01/17/the-chinaluxury-downturn-is-real-global-luxury-brands-must-adjust/. Accessed 21 September 2015.

Zhengping, L., 2011, Chinese Wine. Cambridge: Cambridge University Press.

Zhou, C., 2015, Who Will Buy "Masstige" Wines in China? Available at:

http://www.wineintelligence.com/who-will-buy-masstige-wines-in-china/. Accessed 30 September 2015. 
Table 1

Price (in USD), trading activity and Parker score per Château

\begin{tabular}{|c|c|c|c|c|c|c|c|c|c|c|c|c|c|c|c|c|}
\hline \multirow[b]{2}{*}{ Château } & \multirow[b]{2}{*}{ Region } & \multirow[b]{2}{*}{ Rank } & \multicolumn{7}{|c|}{ Worldwide (without HK) } & \multicolumn{7}{|c|}{ Hong-Kong (only) } \\
\hline & & & $\begin{array}{c}\text { Average } \\
\text { Price }\end{array}$ & $\begin{array}{l}\text { Median } \\
\text { Price }\end{array}$ & $\begin{array}{l}\text { Nobs } \\
{[\text { in \%] }}\end{array}$ & $\begin{array}{c}\text { Turnover } \\
\text { [in \%] }\end{array}$ & $\begin{array}{l}\text { Av. Parker } \\
\text { score }\end{array}$ & $\begin{array}{l}\text { Average } \\
\text { lot size }\end{array}$ & $\begin{array}{l}\text { OWC } \\
\text { [in \%] }\end{array}$ & $\begin{array}{c}\text { Average } \\
\text { Price }\end{array}$ & $\begin{array}{l}\text { Median } \\
\text { Price }\end{array}$ & $\begin{array}{l}\text { Nobs } \\
{[\text { in \%] }}\end{array}$ & $\begin{array}{c}\text { Turnover } \\
\text { [in \%] }\end{array}$ & $\begin{array}{l}\text { Av. Parker } \\
\text { score }\end{array}$ & $\begin{array}{l}\text { Average } \\
\text { lot size }\end{array}$ & $\begin{array}{l}\text { OWC } \\
{[\text { in } \%]}\end{array}$ \\
\hline Angélus & St-Emilion & $1 \mathrm{~A}$ & 216 & 203 & $1.5 \%$ & $0.4 \%$ & 93.7 & 10.50 & $71 \%$ & $301 * * *$ & 290 & $0.4 \%$ & $0.2 \%$ & 95.9 & 11.95 & $88 \%$ \\
\hline Ausone & St-Emilion & $1 \mathrm{~A}$ & 673 & 447 & $1.3 \%$ & $0.9 \%$ & 92.5 & 8.11 & $46 \%$ & & 833 & $0.7 \%$ & $1.0 \%$ & 95.8 & 10.28 & $73 \%$ \\
\hline Cheval Blanc & St-Emilion & $1 \mathrm{~A}$ & 749 & 436 & $4.9 \%$ & $3.3 \%$ & 92.2 & 8.55 & $52 \%$ & $914^{* * *}$ & 620 & $2.2 \%$ & $2.5 \%$ & 94.2 & 10.93 & $82 \%$ \\
\hline Haut Brion & Pessac-Léognan & $1 \mathrm{gcc}$ & 581 & 397 & $7.3 \%$ & $4.6 \%$ & 94.5 & 9.23 & $59 \%$ & $749 * * *$ & 542 & $3.2 \%$ & $3.4 \%$ & 95.7 & 11.24 & $85 \%$ \\
\hline Lafite Rothschild & Pauillac & $1 \mathrm{gcc}$ & $1^{\prime} 080$ & 825 & $11.5 \%$ & $13.2 \%$ & 94.8 & 8.55 & $52 \%$ & & 1'119 & $5.7 \%$ & $12.1 \%$ & 96.5 & 10.76 & $79 \%$ \\
\hline Lafleur & Pomerol & NC & 995 & 605 & $1.3 \%$ & $1.0 \%$ & 94.3 & 7.01 & $34 \%$ & 1132 & 655 & $0.8 \%$ & $0.9 \%$ & 94.9 & 8.93 & $55 \%$ \\
\hline Latour & Pauillac & $1 \mathrm{gcc}$ & 761 & 528 & $8.4 \%$ & $6.4 \%$ & 94.2 & 8.80 & $53 \%$ & & 839 & $3.7 \%$ & $5.6 \%$ & 95.8 & 10.76 & $81 \%$ \\
\hline Margaux & Margaux & $1 \mathrm{gcc}$ & 568 & 491 & $8.0 \%$ & $5.2 \%$ & 95.0 & 9.04 & $57 \%$ & $754 * * *$ & 650 & $3.4 \%$ & $3.9 \%$ & 96.8 & 11.26 & $84 \%$ \\
\hline Mission Haut Brion & Pessac-Léognan & $\mathrm{NC}$ & 596 & 408 & $3.2 \%$ & $1.7 \%$ & 95.5 & 8.85 & $56 \%$ & $708^{* * *}$ & 552 & $1.6 \%$ & $1.4 \%$ & 96.6 & 12.05 & $81 \%$ \\
\hline Mouton Rothschild & Pauillac & $1 \mathrm{gcc}$ & 677 & 386 & $11.2 \%$ & $7.3 \%$ & 93.5 & 9.25 & $59 \%$ & $960 * * *$ & 576 & $4.4 \%$ & $5.3 \%$ & 95.3 & 11.11 & $84 \%$ \\
\hline Pavie & St-Emilion & $1 \mathrm{~A}$ & 222 & 182 & $1.6 \%$ & $0.5 \%$ & 94.5 & 10.94 & $77 \%$ & $311^{* * *}$ & 288 & $0.6 \%$ & $0.3 \%$ & 97.0 & 12.15 & $93 \%$ \\
\hline Pétrus & Pomerol & $\mathrm{NC}$ & $2^{\prime} 024$ & 1'553 & $5.5 \%$ & $8.0 \%$ & 93.7 & 5.58 & $25 \%$ & & $2^{\prime} 225$ & $2.4 \%$ & $7.0 \%$ & 95.0 & 8.03 & $47 \%$ \\
\hline Le Pin & Pomerol & $\mathrm{NC}$ & $1^{\prime} 863$ & 1'546 & $0.7 \%$ & $0.9 \%$ & 93.6 & 5.32 & $20 \%$ & & $2^{\prime} 002$ & $0.5 \%$ & $1.0 \%$ & 94.3 & 7.23 & $35 \%$ \\
\hline Yquem & Sauternes & 1 sup & 660 & 400 & $3.4 \%$ & $1.5 \%$ & 95.8 & 6.94 & $38 \%$ & 613 & 436 & $0.9 \%$ & $0.6 \%$ & 96.6 & 10.00 & $69 \%$ \\
\hline
\end{tabular}

$1 \mathrm{gcc}$ stands for First Growth (1855 classification); 1A stands for First Growth A (St-Emilion, 2012 classification) and NC stands for "non-classified". "Nobs" stands for number of observations; "Av. Parker score" stands for average Parker score; "Average lot size" corresponds to the average number of bottles per lot; "OWC [in \%]" stands for the percentage of wine lots sold in their original wooden case.

"***", "**" and "*" denote that the average price in Hong-Kong is significantly different from elsewhere at the 10\%, 5\% and 1\%-level respectively. 
Table 2

Price (in USD), trading activity and Parker score per Vintage

\begin{tabular}{|c|c|c|c|c|c|c|c|c|c|c|c|c|c|c|}
\hline \multirow[b]{2}{*}{ Vintage } & \multicolumn{7}{|c|}{ Worldwide (without HK) } & \multicolumn{7}{|c|}{ Hong-Kong (only) } \\
\hline & $\begin{array}{c}\text { Average } \\
\text { Price }\end{array}$ & $\begin{array}{l}\text { Median } \\
\text { Price }\end{array}$ & $\begin{array}{l}\text { Nobs } \\
{[\text { in \%] }}\end{array}$ & $\begin{array}{c}\text { Turnover } \\
{[\text { in } \%]}\end{array}$ & $\begin{array}{l}\text { Av. Parker } \\
\text { score }\end{array}$ & $\begin{array}{l}\text { Average } \\
\text { lot size }\end{array}$ & $\begin{array}{l}\text { OWC } \\
\text { [in \%] }\end{array}$ & $\begin{array}{c}\text { Average } \\
\text { Price }\end{array}$ & $\begin{array}{c}\text { Median } \\
\text { Price }\end{array}$ & $\begin{array}{l}\text { Nobs } \\
{[\text { in \%] }}\end{array}$ & $\begin{array}{c}\text { Turnover } \\
{[\text { in } \%]}\end{array}$ & $\begin{array}{l}\text { Av. Parker } \\
\text { score }\end{array}$ & $\begin{array}{l}\text { Average } \\
\text { lot size }\end{array}$ & $\begin{array}{l}\text { OWC } \\
\text { [in \%] }\end{array}$ \\
\hline 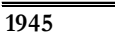 & 3'850 & $22^{\prime} 468$ & $0.7 \%$ & $0.8 \%$ & 97.2 & 2.18 & $4 \%$ & $6346 * * *$ & 3'848 & $0.2 \%$ & $0.6 \%$ & 97.1 & 3.47 & $14 \%$ \\
\hline 1947 & $3^{\prime} 285$ & $2^{\prime} 057$ & $0.5 \%$ & $0.4 \%$ & 98.1 & 2.00 & $3 \%$ & $5968 * * *$ & $4^{\prime} 433$ & $0.1 \%$ & $0.3 \%$ & 98.7 & 3.65 & $16 \%$ \\
\hline 1948 & $1^{\prime} 546$ & $1 ' 202$ & $0.1 \%$ & $0.1 \%$ & 93.7 & 1.96 & $1 \%$ & 2195 & $1^{\prime} 821$ & $0.0 \%$ & $0.0 \%$ & 93.7 & 4.33 & $20 \%$ \\
\hline 1949 & $1^{\prime} 946$ & $1^{\prime} 670$ & $0.4 \%$ & $0.2 \%$ & 94.8 & 2.19 & $3 \%$ & $3568^{* * *}$ & $2^{\prime} 845$ & $0.1 \%$ & $0.2 \%$ & 95.8 & 3.92 & $14 \%$ \\
\hline 1950 & $1^{\prime} 257$ & 848 & $0.1 \%$ & $0.1 \%$ & 96.0 & 3.11 & $6 \%$ & 2283 & $1^{\prime} 749$ & $0.0 \%$ & $0.0 \%$ & 98.3 & 4.70 & $19 \%$ \\
\hline 1952 & 825 & 666 & $0.2 \%$ & $0.1 \%$ & 89.4 & 4.01 & $13 \%$ & $1546^{* * *}$ & $1^{\prime} 260$ & $0.1 \%$ & $0.1 \%$ & 89.0 & 6.71 & $40 \%$ \\
\hline 1953 & 1'101 & 945 & $0.3 \%$ & $0.1 \%$ & 96.4 & 3.09 & $5 \%$ & $1971 * * *$ & 1'501 & $0.1 \%$ & $0.1 \%$ & 97.0 & 4.78 & $19 \%$ \\
\hline 1955 & $1^{\prime} 045$ & 939 & $0.5 \%$ & $0.2 \%$ & 96.6 & 3.25 & $8 \%$ & $1719 * * *$ & 1'562 & $0.1 \%$ & $0.1 \%$ & 96.8 & 3.56 & $8 \%$ \\
\hline 1957 & 552 & 467 & $0.1 \%$ & $0.0 \%$ & 87.7 & 3.64 & $7 \%$ & 887 & 840 & $0.0 \%$ & $0.0 \%$ & 87.6 & 5.36 & $27 \%$ \\
\hline 1959 & 1'844 & $1^{\prime} 708$ & $1.0 \%$ & $0.8 \%$ & 96.7 & 3.05 & $7 \%$ & $2580 * * *$ & 2'316 & $0.3 \%$ & $0.6 \%$ & 96.9 & 5.56 & $24 \%$ \\
\hline 1961 & $1^{\prime} 990$ & $1^{\prime} 653$ & $1.1 \%$ & $1.1 \%$ & 96.3 & 3.74 & $11 \%$ & $3354 * * *$ & $2^{\prime} 511$ & $0.3 \%$ & $0.8 \%$ & 97.4 & 5.13 & $23 \%$ \\
\hline 1962 & 795 & 592 & $0.3 \%$ & $0.1 \%$ & 90.1 & 4.99 & $15 \%$ & 1110 & 774 & $0.0 \%$ & $0.0 \%$ & 90.1 & 5.15 & $10 \%$ \\
\hline 1964 & 724 & 424 & $0.4 \%$ & $0.2 \%$ & 88.9 & 5.90 & $22 \%$ & $1205^{* * *}$ & 865 & $0.1 \%$ & $0.1 \%$ & 91.4 & 8.47 & $52 \%$ \\
\hline 1966 & 570 & 412 & $0.8 \%$ & $0.4 \%$ & 88.8 & 6.72 & $26 \%$ & $857^{* * * *}$ & 625 & $0.2 \%$ & $0.1 \%$ & 88.8 & 8.48 & $49 \%$ \\
\hline 1967 & 948 & $1^{\prime} 020$ & $0.4 \%$ & $0.2 \%$ & 88.2 & 5.10 & $19 \%$ & 1122 & 1'161 & $0.1 \%$ & $0.1 \%$ & 88.6 & 7.88 & $36 \%$ \\
\hline 1969 & 486 & 283 & $0.1 \%$ & $0.0 \%$ & 68.0 & 5.43 & $14 \%$ & 936 & 740 & $0.0 \%$ & $0.0 \%$ & 68.6 & 11.17 & $50 \%$ \\
\hline 1970 & 537 & 309 & $1.3 \%$ & $0.6 \%$ & 89.1 & 8.02 & $42 \%$ & $943^{* * *}$ & 559 & $0.3 \%$ & $0.3 \%$ & 90.4 & 9.40 & $59 \%$ \\
\hline 1971 & 653 & 351 & $0.4 \%$ & $0.2 \%$ & 86.5 & 6.82 & $29 \%$ & $1145^{* * *}$ & $1^{\prime} 015$ & $0.1 \%$ & $0.1 \%$ & 90.2 & 7.29 & $37 \%$ \\
\hline 1972 & 383 & 271 & $0.1 \%$ & $0.0 \%$ & 75.0 & 6.87 & $31 \%$ & 668 & 552 & $0.0 \%$ & $0.0 \%$ & 78.7 & 10.80 & $60 \%$ \\
\hline 1973 & 338 & 266 & $0.2 \%$ & $0.1 \%$ & 71.9 & 8.79 & $46 \%$ & 553 & 464 & $0.0 \%$ & $0.0 \%$ & 71.4 & 9.13 & $50 \%$ \\
\hline 1974 & 378 & 268 & $0.1 \%$ & $0.0 \%$ & 73.6 & 7.74 & $37 \%$ & $648^{* *}$ & 813 & $0.0 \%$ & $0.0 \%$ & 73.6 & 11.13 & $81 \%$ \\
\hline 1975 & 656 & 460 & $1.3 \%$ & $0.7 \%$ & 93.2 & 7.49 & $38 \%$ & $1036^{* * *}$ & 833 & $0.3 \%$ & $0.4 \%$ & 94.4 & 9.01 & $56 \%$ \\
\hline 1976 & 439 & 377 & $0.6 \%$ & $0.3 \%$ & 87.8 & 7.77 & $41 \%$ & $712^{* * *}$ & 632 & $0.1 \%$ & $0.1 \%$ & 91.1 & 9.12 & $57 \%$ \\
\hline 1977 & 410 & 273 & $0.1 \%$ & $0.0 \%$ & 70.2 & 7.37 & $35 \%$ & 538 & 457 & $0.0 \%$ & $0.0 \%$ & 70.0 & 9.00 & $29 \%$ \\
\hline 1978 & 366 & 258 & $0.9 \%$ & $0.4 \%$ & 87.2 & 9.12 & $54 \%$ & $637^{* * *}$ & 444 & $0.2 \%$ & $0.1 \%$ & 88.2 & 10.55 & $72 \%$ \\
\hline 1979 & 444 & 276 & $0.7 \%$ & $0.3 \%$ & 87.5 & 8.52 & $50 \%$ & $886^{* * *}$ & 781 & $0.1 \%$ & $0.1 \%$ & 88.6 & 9.68 & $63 \%$ \\
\hline 1980 & 400 & 251 & $0.2 \%$ & $0.1 \%$ & 85.6 & 8.28 & $49 \%$ & 468 & 264 & $0.0 \%$ & $0.0 \%$ & 81.8 & 14.71 & $76 \%$ \\
\hline 1981 & 391 & 273 & $0.7 \%$ & $0.3 \%$ & 87.2 & 9.26 & $55 \%$ & $635^{* * *}$ & 421 & $0.1 \%$ & $0.1 \%$ & 87.5 & 9.99 & $64 \%$ \\
\hline 1982 & $1^{\prime} 641$ & 1'127 & $5.9 \%$ & $8.7 \%$ & 97.3 & 7.14 & $39 \%$ & $2261 * * *$ & 1'496 & $2.5 \%$ & $7.0 \%$ & 97.6 & 9.80 & $69 \%$ \\
\hline 1983 & 495 & 434 & $1.9 \%$ & $1.1 \%$ & 92.7 & 8.65 & $52 \%$ & $629 * * *$ & 523 & $0.4 \%$ & $0.4 \%$ & 92.9 & 10.27 & $70 \%$ \\
\hline 1984 & 387 & 242 & $0.2 \%$ & $0.1 \%$ & 83.8 & 9.10 & $54 \%$ & 540 & 369 & $0.0 \%$ & $0.0 \%$ & 83.3 & 11.83 & $83 \%$ \\
\hline 1985 & 517 & 401 & $1.9 \%$ & $1.0 \%$ & 90.5 & 8.66 & $52 \%$ & $653^{* * *}$ & 476 & $0.5 \%$ & $0.4 \%$ & 90.6 & 10.48 & $75 \%$ \\
\hline 1986 & 732 & 647 & $3.6 \%$ & $3.1 \%$ & 96.6 & 8.98 & $52 \%$ & $990 * * *$ & 850 & $1.4 \%$ & $2.0 \%$ & 97.6 & 10.77 & $80 \%$ \\
\hline 1987 & 370 & 270 & $0.4 \%$ & $0.2 \%$ & 87.4 & 9.73 & $62 \%$ & 548 & 421 & $0.0 \%$ & $0.0 \%$ & 87.1 & 11.49 & $80 \%$ \\
\hline 1988 & 462 & 357 & $2.0 \%$ & $1.0 \%$ & 91.4 & 9.31 & $58 \%$ & $699 * * *$ & 453 & $0.4 \%$ & $0.4 \%$ & 91.4 & 10.75 & $77 \%$ \\
\hline 1989 & 923 & 629 & $3.6 \%$ & $3.4 \%$ & 94.4 & 8.54 & $51 \%$ & $1319 * * *$ & 1'046 & $1.5 \%$ & $2.7 \%$ & 95.8 & 10.60 & $76 \%$ \\
\hline 1990 & 930 & 706 & $4.2 \%$ & $4.0 \%$ & 96.0 & 8.52 & $50 \%$ & $1207^{* * *}$ & 916 & $1.9 \%$ & $3.2 \%$ & 96.7 & 10.69 & $79 \%$ \\
\hline 1991 & 338 & 275 & $0.3 \%$ & $0.1 \%$ & 87.1 & 10.02 & $68 \%$ & $614 * * *$ & 421 & $0.0 \%$ & $0.0 \%$ & 87.0 & 11.79 & $92 \%$ \\
\hline 1992 & 448 & 317 & $0.4 \%$ & $0.2 \%$ & 87.9 & 9.47 & $59 \%$ & $711^{* * *}$ & 571 & $0.1 \%$ & $0.1 \%$ & 88.3 & 10.42 & $72 \%$ \\
\hline 1993 & 386 & 284 & $1.0 \%$ & $0.5 \%$ & 89.4 & 9.99 & $66 \%$ & $545^{* * *}$ & 366 & $0.2 \%$ & $0.2 \%$ & 89.7 & 11.53 & $84 \%$ \\
\hline 1994 & 402 & 287 & $1.4 \%$ & $0.7 \%$ & 91.8 & 10.15 & $70 \%$ & $592^{* * *}$ & 415 & $0.3 \%$ & $0.3 \%$ & 92.0 & 11.20 & $82 \%$ \\
\hline 1995 & 509 & 410 & $3.8 \%$ & $2.4 \%$ & 95.0 & 9.80 & $65 \%$ & $737^{* * * *}$ & 529 & $2.1 \%$ & $2.3 \%$ & 95.1 & 11.79 & $89 \%$ \\
\hline 1996 & 644 & 589 & $4.0 \%$ & $3.4 \%$ & 96.1 & 10.20 & $71 \%$ & $943^{* * *}$ & 780 & $2.1 \%$ & $3.0 \%$ & 97.2 & 11.60 & $90 \%$ \\
\hline 1997 & 392 & 292 & $1.2 \%$ & $0.6 \%$ & 90.2 & 10.48 & $66 \%$ & $641^{* * *}$ & 395 & $0.3 \%$ & $0.2 \%$ & 90.3 & 11.41 & $79 \%$ \\
\hline 1998 & 636 & 405 & $3.0 \%$ & $2.2 \%$ & 95.2 & 9.89 & $67 \%$ & $911 * * *$ & 555 & $1.6 \%$ & $2.0 \%$ & 95.8 & 11.82 & $82 \%$ \\
\hline 1999 & 461 & 357 & $1.9 \%$ & $1.1 \%$ & 93.7 & 9.80 & $67 \%$ & $644 * * *$ & 451 & $0.7 \%$ & $0.6 \%$ & 93.7 & 11.54 & $85 \%$ \\
\hline 2000 & 1'149 & 937 & $4.8 \%$ & $6.1 \%$ & 98.6 & 8.76 & $55 \%$ & $1466^{* * *}$ & 1'162 & $3.4 \%$ & $6.8 \%$ & 98.6 & 10.77 & $79 \%$ \\
\hline 2001 & 533 & 398 & $1.7 \%$ & $1.0 \%$ & 94.3 & 9.59 & $62 \%$ & $715^{* * *}$ & 553 & $0.9 \%$ & $0.8 \%$ & 94.8 & 10.88 & $79 \%$ \\
\hline 2002 & 431 & 351 & $1.5 \%$ & $0.8 \%$ & 92.7 & 10.31 & $71 \%$ & $629 * * *$ & 472 & $0.7 \%$ & $0.6 \%$ & 92.8 & 11.56 & $88 \%$ \\
\hline 2003 & 629 & 484 & $2.7 \%$ & $2.1 \%$ & 97.4 & 9.81 & $65 \%$ & $830^{* * *}$ & 650 & $2.4 \%$ & $3.0 \%$ & 97.6 & 11.55 & $88 \%$ \\
\hline 2004 & 448 & 345 & $1.3 \%$ & $0.7 \%$ & 93.1 & 10.02 & $69 \%$ & $600^{* * *}$ & 423 & $0.9 \%$ & $0.8 \%$ & 93.2 & 11.88 & $90 \%$ \\
\hline 2005 & 894 & 705 & $1.7 \%$ & $1.7 \%$ & 96.9 & 9.39 & $60 \%$ & $1050^{* * *}$ & 784 & $1.6 \%$ & $2.3 \%$ & 96.8 & 10.77 & $79 \%$ \\
\hline 2006 & 525 & 434 & $0.7 \%$ & $0.4 \%$ & 95.7 & 9.89 & $66 \%$ & $659 * * *$ & 527 & $0.7 \%$ & $0.7 \%$ & 96.1 & 11.27 & $88 \%$ \\
\hline 2007 & 481 & 368 & $0.5 \%$ & $0.3 \%$ & 93.0 & 10.62 & $77 \%$ & $643^{* * *}$ & 459 & $0.3 \%$ & $0.3 \%$ & 92.6 & 11.51 & $90 \%$ \\
\hline 2008 & 618 & 490 & $0.5 \%$ & $0.4 \%$ & 95.4 & 9.84 & $67 \%$ & $768^{* * *}$ & 577 & $0.5 \%$ & $0.6 \%$ & 95.8 & 11.60 & $90 \%$ \\
\hline 2009 & 978 & 790 & $0.2 \%$ & $0.2 \%$ & 99.4 & 9.41 & $60 \%$ & 1162 & 856 & $0.2 \%$ & $0.4 \%$ & 99.4 & 10.94 & $83 \%$ \\
\hline
\end{tabular}

"Nobs" stands for number of observations; "Av. Parker score" for average Parker score; "Average lot size" corresponds to the average number of bottles per lot; "OWC [in \%]" the percentage of wine lots sold in original wooden case.

"***", "**" and "*" denote that the average price in Hong-Kong is significantly different from elsewhere at the 10\%, 5\% and 1\%-level respectively. 
Table 3a

Price (in USD) and trading activity per year

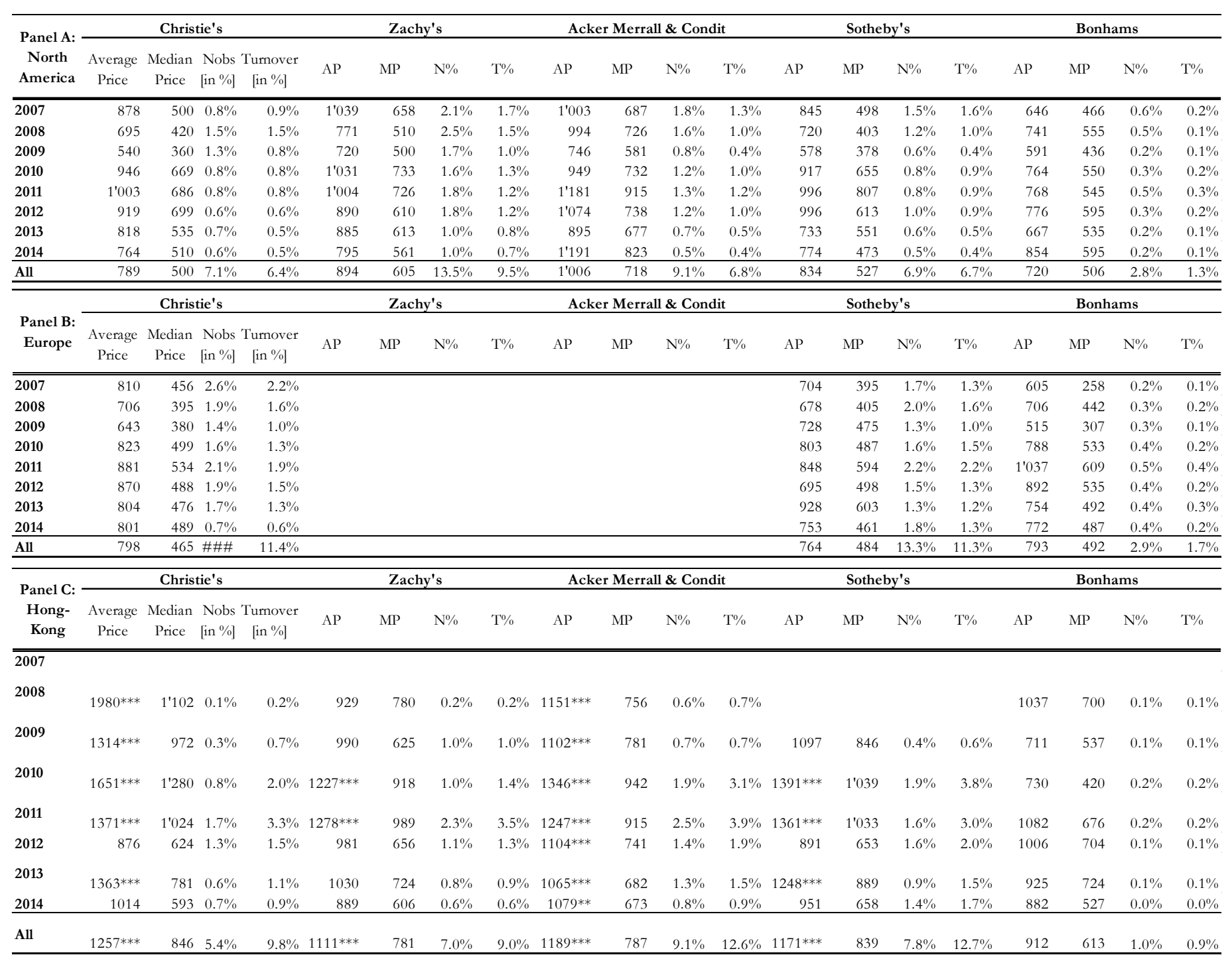

Nobs" stands for number of observations; "***", "**" and "*" denote that the average price in Hong-Kong is significantly different from elsewhere at the $10 \%, 5 \%$ and $1 \%$-level respectively. 
Table 3b

Parker score and lot specificities per year

\begin{tabular}{|c|c|c|c|c|c|c|c|c|c|c|c|c|c|c|c|}
\hline \multirow{2}{*}{$\begin{array}{c}\text { Panel A: } \\
\text { North } \\
\text { America }\end{array}$} & \multicolumn{3}{|c|}{ Christie's } & \multicolumn{3}{|c|}{ Zachy's } & \multicolumn{3}{|c|}{ Acker Merrall \& Condit } & \multicolumn{3}{|c|}{ Sotheby's } & \multicolumn{3}{|c|}{ Bonhams } \\
\hline & $\begin{array}{l}\text { Av. Parker } \\
\text { score }\end{array}$ & $\begin{array}{l}\text { Average } \\
\text { lot size }\end{array}$ & $\begin{array}{l}\text { OWC } \\
\text { [in \%] }\end{array}$ & $\begin{array}{c}\text { Av. } \\
\text { Parker } \\
\text { score } \\
\end{array}$ & $\begin{array}{c}\text { Average } \\
\text { lot size } \\
\end{array}$ & $\begin{array}{l}\text { OWC } \\
\text { [in \%] } \\
\end{array}$ & $\begin{array}{c}\text { Av. Parker } \\
\text { score } \\
\end{array}$ & $\begin{array}{c}\text { Average } \\
\text { lot size }\end{array}$ & $\begin{array}{l}\text { OWC } \\
\text { [in \%] }\end{array}$ & $\begin{array}{c}\text { Av. Parker } \\
\text { score } \\
\end{array}$ & $\begin{array}{c}\text { Average } \\
\text { lot size } \\
\end{array}$ & $\begin{array}{l}\text { OWC } \\
\text { [in \%] } \\
\end{array}$ & $\begin{array}{c}\text { Av. Parker } \\
\text { score } \\
\end{array}$ & $\begin{array}{l}\text { Average } \\
\text { lot size }\end{array}$ & $\begin{array}{l}\text { OWC } \\
\text { [in \%] } \\
\end{array}$ \\
\hline 2007 & 93.9 & 10.8 & $76 \%$ & 94.5 & 7.8 & $45 \%$ & 95.8 & 6.2 & $30 \%$ & 94.5 & 10.8 & $79 \%$ & 94.7 & 6.3 & $34 \%$ \\
\hline 2008 & 94.3 & 10.8 & $82 \%$ & 94.8 & 7.5 & $42 \%$ & 95.6 & 6.5 & $33 \%$ & 92.9 & 10.5 & $73 \%$ & 94.0 & 5.0 & $22 \%$ \\
\hline 2009 & 93.7 & 10.0 & $69 \%$ & 95.0 & 7.8 & $43 \%$ & 95.6 & 6.7 & $35 \%$ & 93.9 & 10.4 & $69 \%$ & 95.4 & 5.2 & $19 \%$ \\
\hline 2010 & 94.8 & 8.7 & $51 \%$ & 95.2 & 7.4 & $42 \%$ & 95.9 & 8.0 & $45 \%$ & 95.6 & 10.1 & $70 \%$ & 94.9 & 6.6 & $31 \%$ \\
\hline 2011 & 93.5 & 8.9 & $56 \%$ & 95.0 & 6.8 & $36 \%$ & 95.5 & 8.0 & $45 \%$ & 94.8 & 9.0 & $53 \%$ & 93.3 & 6.1 & $29 \%$ \\
\hline 2012 & 95.9 & 8.5 & $51 \%$ & 94.9 & 7.4 & $40 \%$ & 95.8 & 7.5 & $37 \%$ & 94.3 & 9.4 & $61 \%$ & 93.8 & 6.8 & $34 \%$ \\
\hline 2013 & 94.5 & 7.6 & $42 \%$ & 95.2 & 8.3 & $49 \%$ & 95.5 & 7.5 & $37 \%$ & 95.3 & 9.1 & $55 \%$ & 94.0 & 6.7 & $29 \%$ \\
\hline 2014 & 94.3 & 8.6 & $54 \%$ & 95.1 & 8.2 & $47 \%$ & 95.4 & 7.1 & $34 \%$ & 93.4 & 9.0 & $55 \%$ & 92.0 & 5.5 & $23 \%$ \\
\hline All & 94.3 & 9.5 & $64 \%$ & 94.9 & 7.6 & $42 \%$ & 95.7 & 7.1 & $37 \%$ & 94.3 & 9.9 & $67 \%$ & 94.1 & 6.0 & $29 \%$ \\
\hline \multirow[b]{2}{*}{$\begin{array}{c}\text { Panel B: } \\
\text { Europe }\end{array}$} & \multicolumn{3}{|c|}{ Christie's } & \multicolumn{3}{|c|}{ Zachy's } & \multicolumn{3}{|c|}{ Acker Merrall \& Condit } & \multicolumn{3}{|c|}{ Sotheby's } & \multicolumn{3}{|c|}{ Bonhams } \\
\hline & $\begin{array}{c}\text { Av. Parker } \\
\text { score } \\
\end{array}$ & $\begin{array}{l}\text { Average } \\
\text { lot size }\end{array}$ & $\begin{array}{l}\text { OWC } \\
\text { [in \%] } \\
\end{array}$ & $\begin{array}{c}\text { Av. } \\
\text { Parker }\end{array}$ & $\begin{array}{c}\text { Average } \\
\text { lot size }\end{array}$ & $\begin{array}{l}\text { OWC } \\
\text { [in \%] }\end{array}$ & $\begin{array}{c}\text { Av. Parker } \\
\text { score }\end{array}$ & $\begin{array}{l}\text { Average } \\
\text { lot size }\end{array}$ & $\begin{array}{l}\text { OWC } \\
\text { [in \%] }\end{array}$ & $\begin{array}{c}\text { Av. Parker } \\
\text { score } \\
\end{array}$ & $\begin{array}{l}\text { Average } \\
\text { lot size } \\
\end{array}$ & $\begin{array}{l}\text { OWC } \\
\text { [in \%] } \\
\end{array}$ & $\begin{array}{c}\text { Av. Parker } \\
\text { score }\end{array}$ & $\begin{array}{c}\text { Average } \\
\text { lot size }\end{array}$ & $\begin{array}{l}\text { OWC } \\
\text { [in \%] }\end{array}$ \\
\hline 2007 & 93.1 & 9.0 & $59 \%$ & & & & & & & 93.2 & 9.3 & $61 \%$ & 90.7 & 8.4 & $53 \%$ \\
\hline 2008 & 92.5 & 10.3 & $57 \%$ & & & & & & & 93.6 & 9.9 & $68 \%$ & 93.2 & 8.3 & $51 \%$ \\
\hline 2009 & 93.6 & 9.7 & $64 \%$ & & & & & & & 94.1 & 9.7 & $66 \%$ & 92.2 & 8.1 & $50 \%$ \\
\hline 2010 & 93.0 & 8.4 & $49 \%$ & & & & & & & 94.3 & 9.7 & $64 \%$ & 93.0 & 7.2 & $37 \%$ \\
\hline 2011 & 92.3 & 9.1 & $56 \%$ & & & & & & & 94.0 & 9.6 & $65 \%$ & 92.6 & 6.9 & $39 \%$ \\
\hline 2012 & 93.2 & 8.6 & $49 \%$ & & & & & & & 94.0 & 9.5 & $64 \%$ & 92.2 & 6.6 & $37 \%$ \\
\hline 2013 & 93.3 & 9.0 & $55 \%$ & & & & & & & 94.7 & 8.9 & $59 \%$ & 93.1 & 8.2 & $51 \%$ \\
\hline 2014 & 93.7 & 9.8 & $68 \%$ & & & & & & & 94.5 & 8.2 & $47 \%$ & 93.6 & 7.0 & $39 \%$ \\
\hline All & 93.0 & 9.2 & $56 \%$ & & & & & & & 94.0 & 9.4 & $62 \%$ & 92.7 & 7.5 & $44 \%$ \\
\hline Panel C: & \multicolumn{3}{|c|}{ Christie's } & \multicolumn{3}{|c|}{ Zachy's } & \multicolumn{3}{|c|}{ Acker Merrall \& Condit } & \multicolumn{3}{|c|}{ Sotheby's } & \multicolumn{3}{|c|}{ Bonhams } \\
\hline $\begin{array}{c}\text { Hong- } \\
\text { Kong } \\
\end{array}$ & $\begin{array}{c}\text { Av. Parker } \\
\text { score } \\
\end{array}$ & $\begin{array}{c}\text { Average } \\
\text { lot size } \\
\end{array}$ & $\begin{array}{l}\text { OWC } \\
\text { [in } \%] \\
\end{array}$ & $\begin{array}{l}\text { Av. } \\
\text { Parker }\end{array}$ & $\begin{array}{c}\text { Average } \\
\text { lot size } \\
\end{array}$ & $\begin{array}{l}\text { OWC } \\
\text { [in \%] } \\
\end{array}$ & $\begin{array}{c}\text { Av. Parker } \\
\text { score } \\
\end{array}$ & $\begin{array}{c}\text { Average } \\
\text { lot size } \\
\end{array}$ & $\begin{array}{l}\text { OWC } \\
\text { [in \%] } \\
\end{array}$ & $\begin{array}{c}\text { Av. Parker } \\
\text { score } \\
\end{array}$ & $\begin{array}{c}\text { Average } \\
\text { lot size } \\
\end{array}$ & $\begin{array}{l}\text { OWC } \\
\text { [in \%] } \\
\end{array}$ & $\begin{array}{c}\text { Av. Parker } \\
\text { score } \\
\end{array}$ & $\begin{array}{c}\text { Average } \\
\text { lot size } \\
\end{array}$ & $\begin{array}{l}\text { OWC } \\
\text { [in \%] } \\
\end{array}$ \\
\hline 2007 & & & & & & & & & & & & & & & \\
\hline 2008 & 95.3 & 13.2 & $85 \%$ & 97.2 & 10.7 & $80 \%$ & 96.5 & 9.4 & $63 \%$ & & & & 95.6 & 9.3 & $68 \%$ \\
\hline 2009 & 96.8 & 23.0 & $91 \%$ & 96.3 & 9.8 & $72 \%$ & 95.7 & 8.3 & $50 \%$ & 95.1 & 11.2 & $86 \%$ & 95.8 & 8.3 & $51 \%$ \\
\hline 2010 & 96.6 & 11.6 & $92 \%$ & 96.1 & 9.8 & $70 \%$ & 96.1 & 10.3 & $75 \%$ & 96.1 & 11.5 & $92 \%$ & 95.8 & 12.3 & $81 \%$ \\
\hline 2011 & 95.9 & 11.3 & $86 \%$ & 95.6 & 9.5 & $63 \%$ & 95.5 & 11.0 & $81 \%$ & 96.1 & 11.2 & $87 \%$ & 93.6 & 7.9 & $48 \%$ \\
\hline 2012 & 95.7 & 11.2 & $87 \%$ & 95.3 & 9.9 & $70 \%$ & 95.6 & 10.5 & $74 \%$ & 96.4 & 10.9 & $81 \%$ & 95.0 & 8.7 & $60 \%$ \\
\hline 2013 & 95.6 & 11.4 & $77 \%$ & 95.9 & 10.3 & $74 \%$ & 95.5 & 10.3 & $73 \%$ & 96.2 & 11.0 & $83 \%$ & 94.7 & 7.3 & $41 \%$ \\
\hline 2014 & 94.5 & 11.7 & $82 \%$ & 95.9 & 10.5 & $80 \%$ & 95.5 & 9.9 & $70 \%$ & 95.9 & 11.3 & $89 \%$ & 95.6 & 8.5 & $59 \%$ \\
\hline All & 95.8 & 12.0 & $86 \%$ & 95.8 & 9.9 & $70 \%$ & 95.7 & 10.3 & $73 \%$ & 96.1 & 11.2 & $87 \%$ & 95.0 & 9.1 & $59 \%$ \\
\hline
\end{tabular}

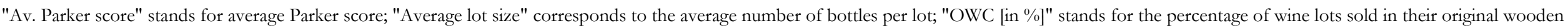
case. 
Table 4

Descriptive statistics and correlation (Parker scores, lot size and price in USD)

\begin{tabular}{|c|c|c|c|c|}
\hline $\begin{array}{c}\text { Panel A: Descriptive } \\
\text { statistics } \\
\end{array}$ & Parker score & Lot size & Price & $\log ($ price $)$ \\
\hline$\overline{\text { Average }}$ & 94.72 & 9.20 & 937.71 & 6.47 \\
\hline Median & 95.00 & 12.00 & 621.00 & 6.43 \\
\hline Standard deviation & 4.93 & 5.49 & $1^{\prime} 082.14$ & 0.83 \\
\hline Skewness & -1.74 & 32.16 & 5.33 & 0.27 \\
\hline Kurtosis & 10.33 & 3'113.73 & 63.83 & 3.14 \\
\hline $\begin{array}{c}\text { Panel B: Cross- } \\
\text { correlations }\end{array}$ & Parker score & Lot size & Price & $\log ($ price $)$ \\
\hline Parker score & & $-0.04 * * *$ & $0.33^{* * * *}$ & $0.51 * * *$ \\
\hline Lot size & & & $-0.19 * * *$ & $-0.22 * * *$ \\
\hline Price & & & & $0.81 * * *$ \\
\hline
\end{tabular}

"***", "**" and "*" denote that the correlation between two variables is significant at the $10 \%$, $5 \%$ and $1 \%$-level respectively. 
Table 5

List of variables used in the hedonic regression

\section{Variables}

Details

Used in specification

A. Variables specific to the wine auctioned :

\begin{tabular}{|c|c|c|c|c|c|c|}
\hline Château & Dummy variables for each Châteaux & $x$ & $x$ & $x$ & $x$ & $x$ \\
\hline Vintage & Dummy variables for vintages 1945 to 2009 & $\times$ & $\times$ & $x$ & $\times$ & $\times$ \\
\hline Rating & $\begin{array}{l}\text { Existence of a Parker's rating (dummy variable), } \\
\text { Parker' score and score }\end{array}$ & $x$ & $x$ & $x$ & $x$ & $x$ \\
\hline OWC-12 & $\begin{array}{l}\text { Dummy variable to control if the wine is sold in the } \\
\text { 12-bottle Original Wooden Case (OWC) }\end{array}$ & $x$ & $x$ & $x$ & $x$ & $x$ \\
\hline Quantity & Number of bottles sold in a particular lot & $x$ & $x$ & $x$ & $x$ & $x$ \\
\hline
\end{tabular}

B. Variables specific to the auction venue :

\begin{tabular}{|c|c|c|c|c|c|c|}
\hline Auction house & $\begin{array}{l}\text { Dummy variables for Acker Merrall \& Condit, } \\
\text { Bonhams, Christie's, Sotheby's, and Zachy's }\end{array}$ & $x$ & $x$ & $x$ & $x$ & $x$ \\
\hline Time of sale & $\begin{array}{l}\text { Dummy variables for January } 2007 \text { to November } \\
2014 \text { (used to construct the index) }\end{array}$ & $x$ & $x$ & $x$ & $x$ & $x$ \\
\hline Auction location & Dummy variables for Europe, USA and Hong-Kong ${ }^{(*)}$ & $x$ & $x$ & $x$ & $x$ & $x$ \\
\hline $\begin{array}{l}\text { Hong-Kong premium } \times \\
\text { Parker score }\end{array}$ & $\begin{array}{l}\text { Dummy variables to estimate the influence of Parker } \\
\text { scores on the Hong-Kong price premium }\end{array}$ & & $x$ & & & \\
\hline $\begin{array}{l}\text { Hong-Kong premium } \times \\
\text { Châteaux }\end{array}$ & $\begin{array}{l}\text { Dummy variables to estimate château-specific Hong- } \\
\text { Kong price premia }\end{array}$ & & & $x$ & & \\
\hline $\begin{array}{l}\text { Hong-Kong premium } \times \\
\text { Châteaux' brand power }\end{array}$ & $\begin{array}{l}\text { Interaction term to assess if the Hong-Kong price } \\
\text { premium depends on the châteaux' brand power }\end{array}$ & & & & $x$ & \\
\hline $\begin{array}{l}\text { Hong-Kong premium } \times \\
\text { time of sale }\end{array}$ & $\begin{array}{l}\text { Interaction terms (set of dummy variables) used to } \\
\text { estimate a time-varying Hong-Kong premium }\end{array}$ & & & & & $x$ \\
\hline
\end{tabular}

We consider five particular hedonic regression specifications; the variables used in each specification are indicated in the column denoted as "used in specification".

Specification 1 is applied to three datasets. The first dataset includes all observations (1a), while the second includes observations from all auction venues except those in Hong-Kong (1b). The third uses only observations from auctions taking place in Hong-Kong (1c).

$\left(^{*}\right)$ : the Hong-Kong dummy variable is used in specification 1 (it would be collinear with the other variables in specifications 2 to 5 ). 
Table 6

The Hong Kong premium

\begin{tabular}{|c|c|c|c|c|c|c|}
\hline & \multicolumn{2}{|c|}{ 1a) All auctions } & \multicolumn{2}{|c|}{ 1b) Without Hong-Kong } & \multicolumn{2}{|c|}{ 1c) Hong-Kong only } \\
\hline & Coeff. & p-value & Coeff. & p-value & Coeff. & p-value \\
\hline Intercept & 6.23 & $<0.01 \%$ & 6.14 & $<0.01 \%$ & 7.37 & $<0.01 \%$ \\
\hline Ausone & 1.05 & $<0.01 \%$ & 1.01 & $<0.01 \%$ & 1.09 & $<0.01 \%$ \\
\hline Cheval Blanc & 0.95 & $<0.01 \%$ & 0.99 & $<0.01 \%$ & 0.83 & $<0.01 \%$ \\
\hline Haut Brion & 0.75 & $<0.01 \%$ & 0.77 & $<0.01 \%$ & 0.69 & $<0.01 \%$ \\
\hline Lafite Rothschild & 1.37 & $<0.01 \%$ & 1.34 & $<0.01 \%$ & 1.38 & $<0.01 \%$ \\
\hline Lafleur & 1.22 & $<0.01 \%$ & 1.25 & $<0.01 \%$ & 1.13 & $<0.01 \%$ \\
\hline Latour & 1.01 & $<0.01 \%$ & 1.02 & $<0.01 \%$ & 0.98 & $<0.01 \%$ \\
\hline Margaux & 0.80 & $<0.01 \%$ & 0.83 & $<0.01 \%$ & 0.74 & $<0.01 \%$ \\
\hline Mission Haut Brion & 0.43 & $<0.01 \%$ & 0.46 & $<0.01 \%$ & 0.34 & $<0.01 \%$ \\
\hline Mouton Rothschild & 0.83 & $<0.01 \%$ & 0.83 & $<0.01 \%$ & 0.82 & $<0.01 \%$ \\
\hline Pavie & -0.09 & $<0.01 \%$ & -0.10 & $<0.01 \%$ & -0.09 & $<0.01 \%$ \\
\hline Pétrus & 2.16 & $<0.01 \%$ & 2.17 & $<0.01 \%$ & 2.11 & $<0.01 \%$ \\
\hline Le Pin & 2.23 & $<0.01 \%$ & 2.22 & $<0.01 \%$ & 2.21 & $<0.01 \%$ \\
\hline Yquem & 0.64 & $<0.01 \%$ & 0.70 & $<0.01 \%$ & 0.43 & $<0.01 \%$ \\
\hline Zachy's & -0.03 & $<0.01 \%$ & 0.02 & $<0.01 \%$ & -0.17 & $<0.01 \%$ \\
\hline Acker Merrall Condit & 0.03 & $<0.01 \%$ & 0.09 & $<0.01 \%$ & -0.09 & $<0.01 \%$ \\
\hline Sotheby's & 0.02 & $<0.01 \%$ & 0.03 & $<0.01 \%$ & -0.05 & $<0.01 \%$ \\
\hline Bonhams & -0.11 & $<0.01 \%$ & -0.08 & $<0.01 \%$ & -0.24 & $<0.01 \%$ \\
\hline Europe & 0.02 & $<0.01 \%$ & 0.05 & $<0.01 \%$ & & \\
\hline Hong-Kong & 0.18 & $<0.01 \%$ & & & & \\
\hline Quantity & -0.00 & $<0.01 \%$ & -0.01 & $<0.01 \%$ & -0.00 & $<0.01 \%$ \\
\hline OWC-12 & 0.02 & $<0.01 \%$ & 0.04 & $<0.01 \%$ & 0.01 & $10.91 \%$ \\
\hline Parker's rating? & 0.51 & $<0.01 \%$ & 0.49 & $<0.01 \%$ & 0.50 & $<0.01 \%$ \\
\hline Parker score & 0.40 & $<0.01 \%$ & 0.41 & $<0.01 \%$ & 0.39 & $<0.01 \%$ \\
\hline Parker score $^{2}$ & 0.04 & $<0.01 \%$ & 0.04 & $<0.01 \%$ & 0.05 & $<0.01 \%$ \\
\hline Observations: & 92538 & & 63947 & & 28229 & \\
\hline $\mathrm{R}^{2}:$ & 0.85 & $<0.01 \%$ & 0.84 & $<0.01 \%$ & 0.87 & $<0.01 \%$ \\
\hline
\end{tabular}

This table indicates results for specification 1. Panel 1a) uses all auction data, 1b) all auction data outside Hong Kong and 1c) Hong Kong auction data only. Control variables comprise dummy variables for the respective châteaux, vintages, auction houses and locations. It further includes the presence of a wooden case, the quantity sold in a lot, a dummy if a Parker score is available as well as Parker Scores and Parker scores squared. The reference (intercept) is Château Angélus 1945 sold in North America at Christie's in January 2007. 
Figure 1

Vintage and wine prices

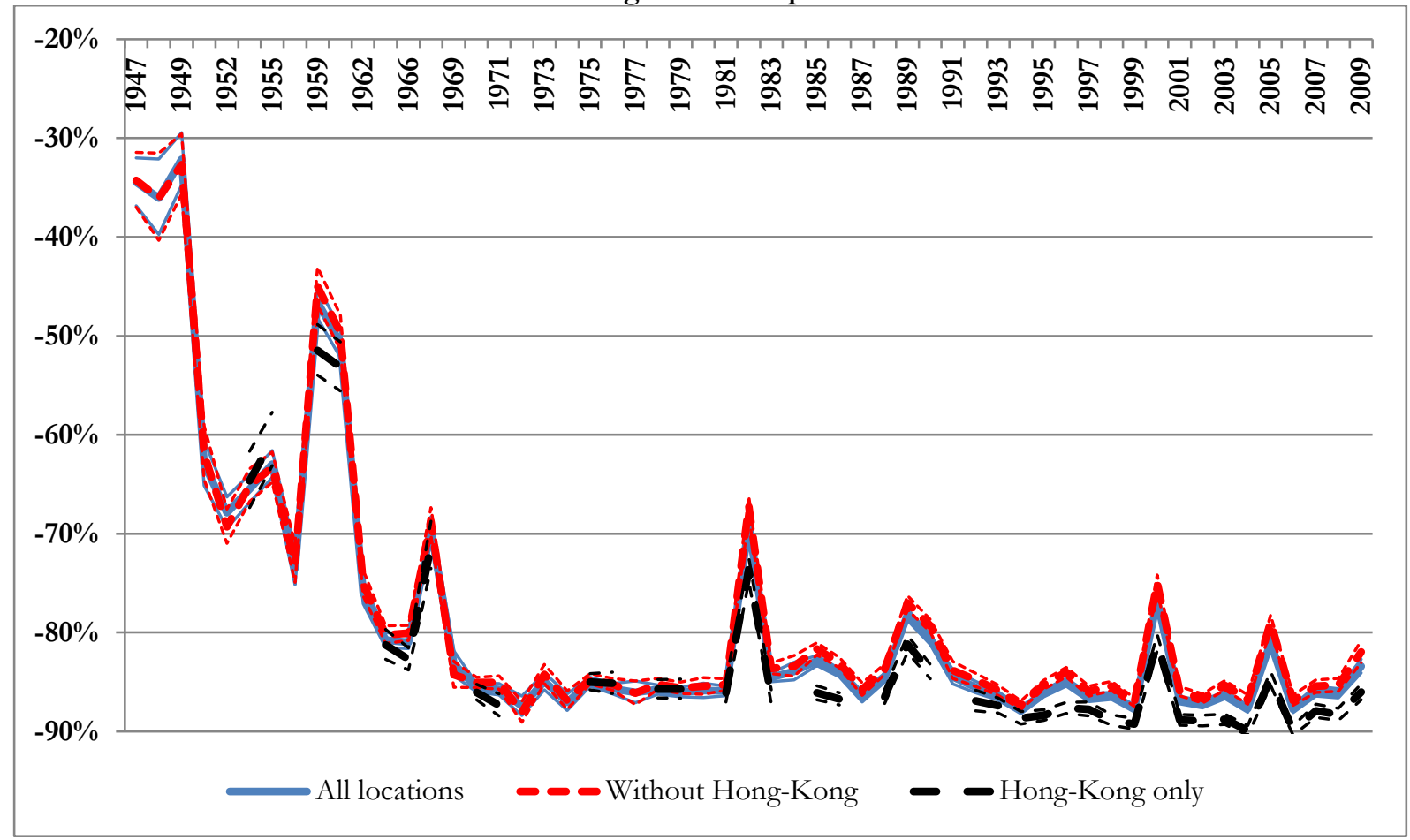

The figure is based on specification 1 (see Table 5) and illustrates the prices of wines traded for each vintage in the sample. It includes 95\%-confidence intervals. 
Figure 2

Auction locations and wine price indices

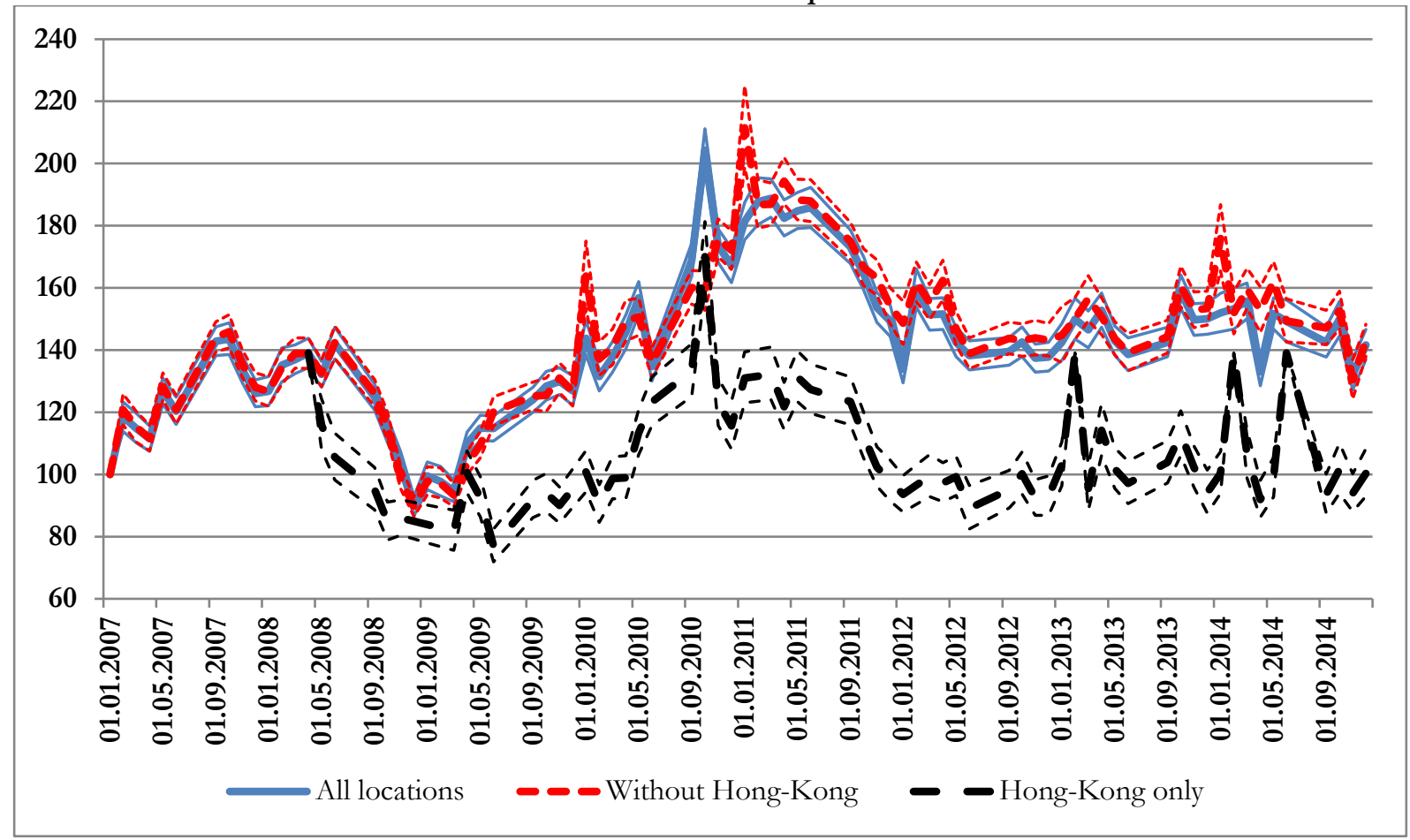

The figure is based on specification 1 (see Table 5) and illustrates the evolution of wines traded at different auction locations. It includes 95\%-confidence intervals. 
Table 7

The Hong Kong premium and wine visibility

\begin{tabular}{|c|c|c|c|c|c|c|c|c|}
\hline \multicolumn{3}{|c|}{ Specification 2} & \multicolumn{3}{|c|}{ Specification 3} & \multicolumn{3}{|c|}{ Specification 4} \\
\hline Parker score & Coeff. & p-value & Château & Coeff. & p-value & Brand power & Coeff. & p-value \\
\hline Not rated & 0.355 & $<0.01 \%$ & Angélus & 0.171 & $<0.01 \%$ & Hong-Kong & 0.233 & $<0.01 \%$ \\
\hline $50-79$ & 0.574 & $<0.01 \%$ & Ausone & 0.288 & $<0.01 \%$ & Hong-Kong $\times$ & \multirow{2}{*}{-0.006} & \multirow{2}{*}{$<0.01 \%$} \\
\hline $80-89$ & 0.320 & $<0.01 \%$ & Cheval Blanc & 0.065 & $<0.01 \%$ & Liv-ex rank & & \\
\hline $90-95$ & 0.187 & $<0.01 \%$ & Haut Brion & 0.132 & $<0.01 \%$ & & & \\
\hline $96-98$ & 0.112 & $<0.01 \%$ & Lafite Rothschild & 0.263 & $<0.01 \%$ & & & \\
\hline 99 & 0.041 & $<0.01 \%$ & Lafleur & 0.100 & $<0.01 \%$ & & & \\
\hline \multirow[t]{8}{*}{100} & 0.205 & $<0.01 \%$ & Latour & 0.198 & $<0.01 \%$ & & & \\
\hline & & & Margaux & 0.121 & $<0.01 \%$ & & & \\
\hline & & & Mission Haut Brion & 0.106 & $<0.01 \%$ & & & \\
\hline & & & Mouton Rothschild & 0.220 & $<0.01 \%$ & & & \\
\hline & & & Pavie & 0.168 & $<0.01 \%$ & & & \\
\hline & & & Pétrus & 0.196 & $<0.01 \%$ & & & \\
\hline & & & Le Pin & 0.203 & $<0.01 \%$ & & & \\
\hline & & & Yquem & -0.015 & $26.15 \%$ & & & \\
\hline
\end{tabular}

This table indicates results for specifications 2 to 4. The reference (intercept) is Château Angélus 1945 sold in North America at Christie's in January 2007. The coefficients that are common with specification 1 are not reported but are very close to those reported in Table 6. 
Figure 3

The declining Hong-Kong premium

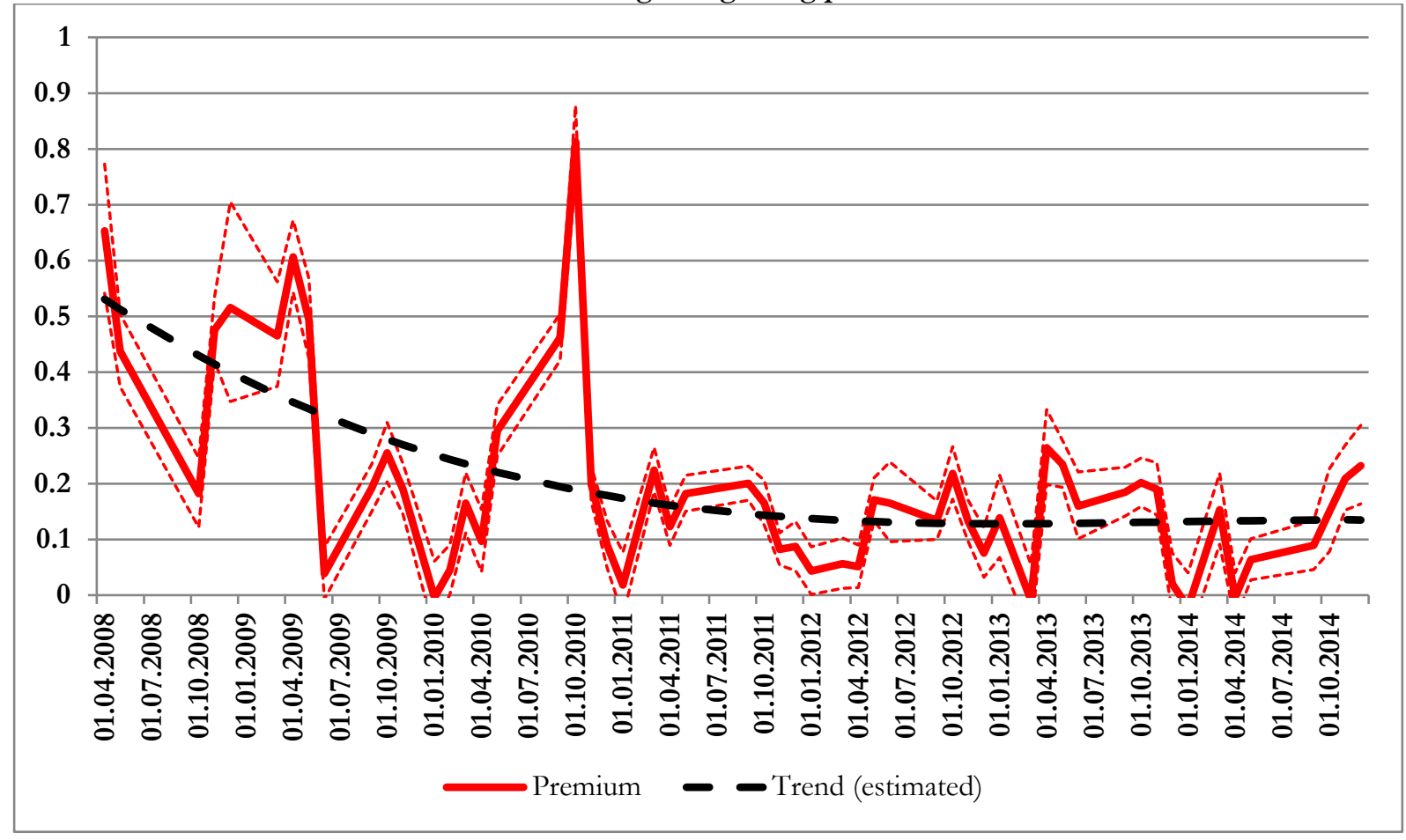

This figure illustrates results for specification 5. It includes $95 \%$-confidence intervals. The trend was estimated using a polynomial model of degree 3 . 
Table 8

Robustness tests

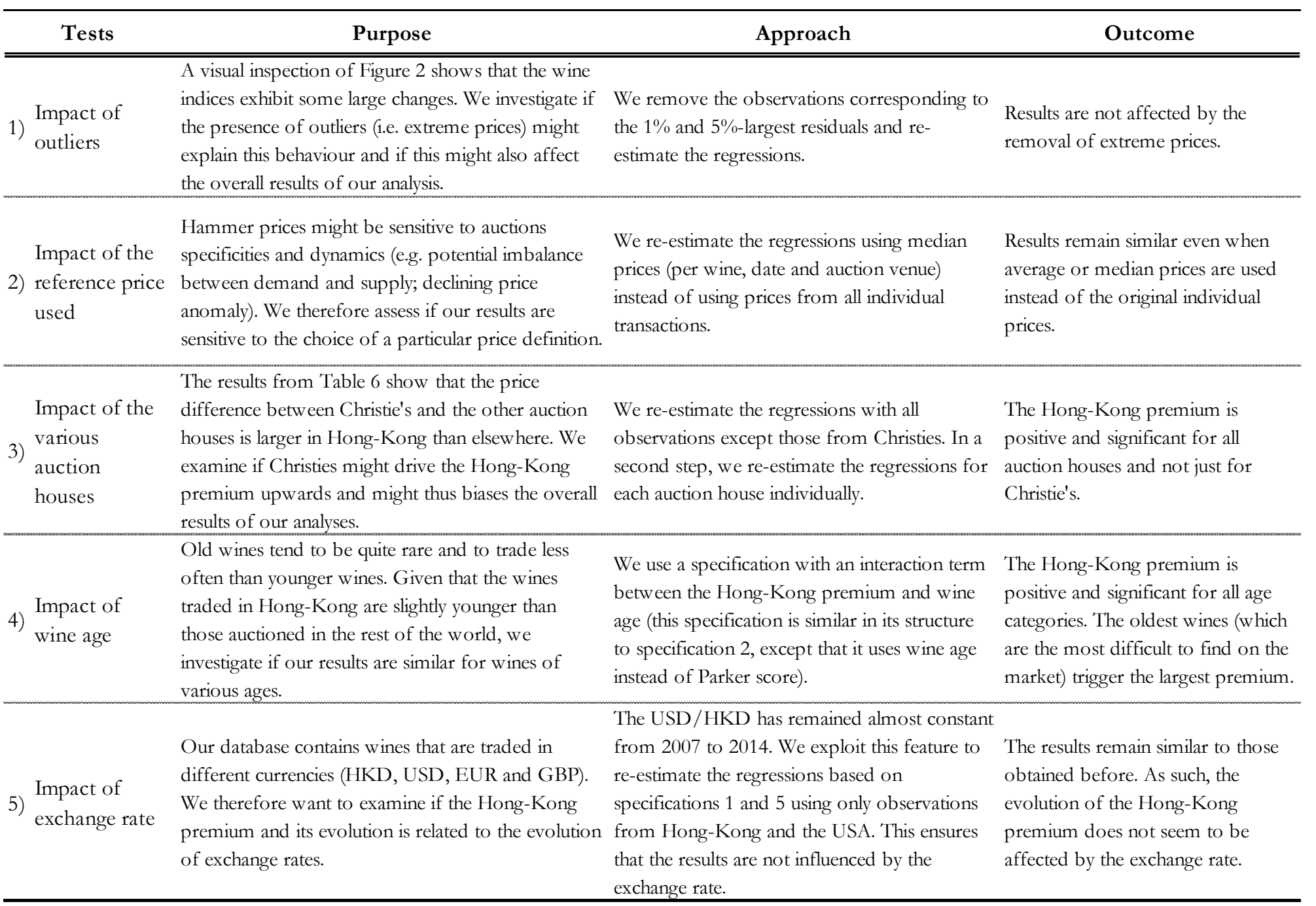

This table presents the five types of robustness tests that were undertaken. We present the motivation underlying each robustness test ("Purpose"), the approach used to run it ("Approach") and the results obtained ("Outcome"). 


\section{Appendix 1}

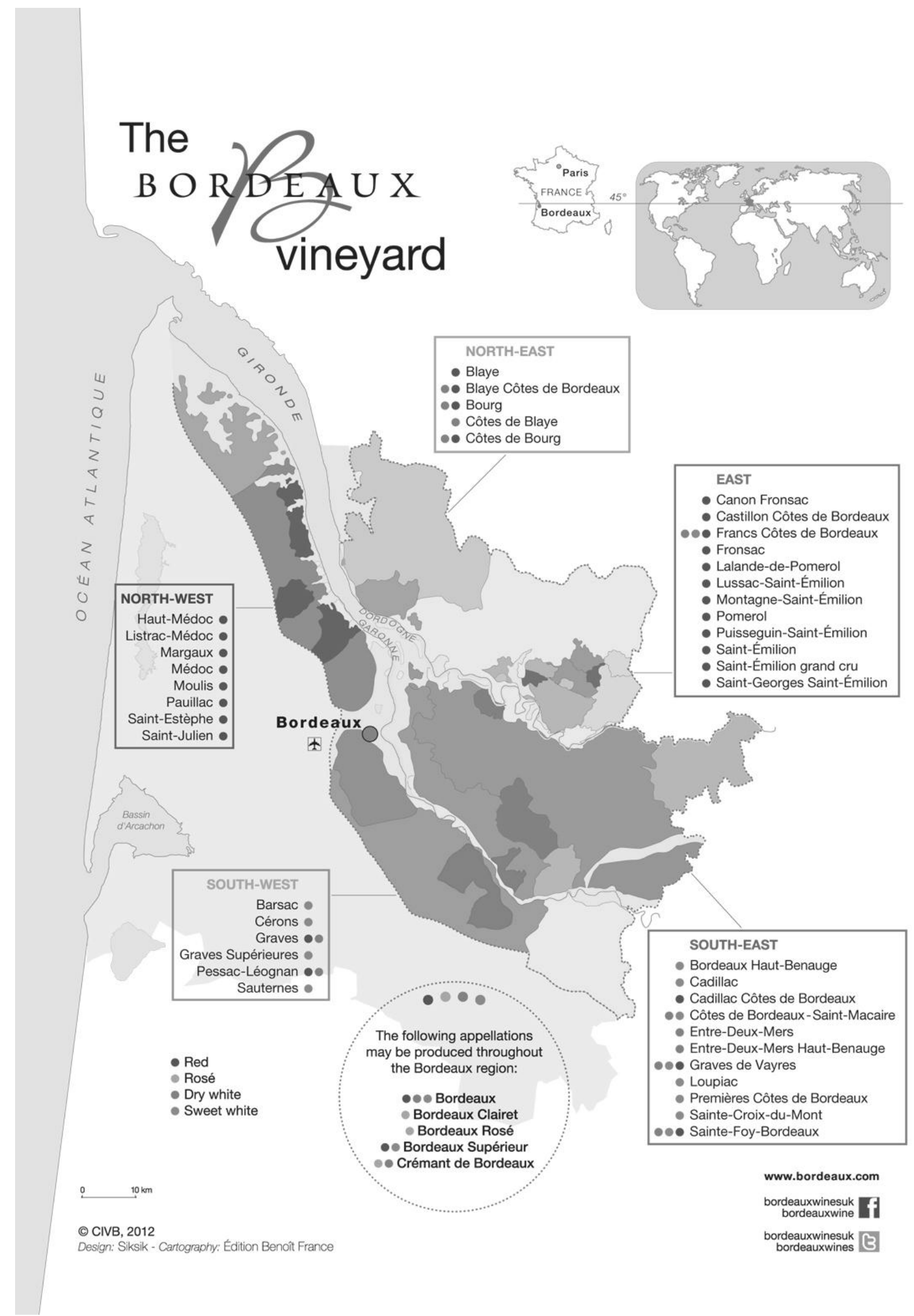

Source: CIVB 


\section{Appendix 2}

\section{Appellations}

- Overall, the Bordeaux wine-growing region can be broadly divided into two distinctive parts: the left bank and the right bank of the Gironde River. The best known appellations for red fine wines are situated in the North-West (Medoc, Margaux, Pauillac, St. Julien, St. Estephe) for the left bank and the East (St. Emilion and Pomerol) for the right bank. For sweet wines the most prestigious wines emanate from the South-West (Barsac and Sauternes). Next to these most prestigious appellations several other appellations exist that constitute the 60 appellations of the Bordeaux regions.

$\underline{\text { Ranking: }}$

- The Medoc \& Pessac appellations have a ranking that is unchanged since 1855 (with the only exception of Mouton Rothschild which got promoted to first growth in 1973). Overall, it classifies the best 61 wines into first to fifth growths.

- St. Emilion has had a ranking since 1954 that is updated more or less every 10 years. The last update was conducted in 2012 with 72 wines categorised into first growth A (2) and B (13) and classified growth (57) wines.

- In Pomerol no official ranking exists, however, some wines have consistently shown superior quality such as Petrus, Lafleur or Le Pin.

- Sweet wines from Sauternes and Barzac are classified as First growth Superior (Yquem), first (11) and second (15) growths. 